Article

\title{
Flood Adaptation Measures Applicable in the Design of Urban Public Spaces: Proposal for a Conceptual Framework
}

\author{
Maria Matos Silva * and João Pedro Costa \\ Universidade de Lisboa, Faculdade de Arquitetura, CIAUD, Centro de Investigação em Arquitetura, \\ Urbanismo e Design, Rua Sá Nogueira, Pólo Universitário do Alto da Ajuda, Lisbon 1349-063, Portugal; \\ jpc@fa.ulisboa.pt \\ * Correspondence: m.matosilva@fa.ulisboa.pt; Tel.: +351-213615884
}

Academic Editor: Peter J. Coombes

Received: 3 May 2016; Accepted: 5 July 2016; Published: 12 July 2016

\begin{abstract}
Assuming the importance of public space design in the implementation of effective adaptation action towards urban flooding, this paper identifies and systematizes a wide range of flood adaptation measures pertinent to the design of public spaces. It presents findings from both a systematic literature review and an empirical analysis retrieved from concrete public space design precedents. It concludes with the presentation of a conceptual framework that organizes the identified measures in accordance to their main, and secondary, infrastructural strategies. The intention behind the disclosed framework is to aid a multitude of professionals during the initial exploratory phases of public space projects that incorporate flooding adaptation capacities.
\end{abstract}

Keywords: climate change; adaptation; flood risk management; public space design; urbanism

\section{Introduction}

Floods are among the most frequent urban hazard, albeit paradoxically experienced as an event attributed to nature's exceptionality. In addition, urban open spaces are among the most vulnerable areas as they are where impacts are more acutely experienced [1]. In light of this problem, there has been an emerging concern for urban territories to take into consideration potential unprecedented climate change impacts. More specifically, such impacts include those associated with extreme weather events, such as extreme precipitation or storm surges, which will likely lead to more frequent and intense episodes of flooding [2]. Possible flood risk management responses within each context (and how such responses can be implemented) must therefore move to the frontline of urban design [3]. A concern has been transposed into the contemporary requirements of our governing agencies, aiming to actively pursue adaptation strategies and measures [4]. If one is to consider a broader perspective, one could moreover argue that climate change is prompting out-of-the-box thinking and urging the need to move beyond traditional and sectorial solutions [5].

Approaching the identified concerns as opportunities rather than hindering constraints, this research is based on the hypothesis that the design of public spaces is determinant for the urban adaptation to flooding events. Urban public spaces are here understood as multifunctional spaces, with a central social, political and cultural significance [6]. With regard to its physical characteristics, the long-lasting permanence of public space as a structuring urban space $[7,8]$ of interdisciplinary nature $[9,10]$ has been emphasized. Overall, public space may be defined by Hanna Arendt's communal table description as a space that "gathers us together and yet prevents our falling over each other, so to speak" [11].

Implicitly, these urban public spaces are here considered as a common entity of shared concerns, which may accommodate civic purposes. At the same time that they are among the most vulnerable 
areas to climatic hazards, and flooding events in particular, they entail specific characteristics that are particularly relevant for adaptation efforts. Amongst other urban constituents, both people and communities should be perceived as more than susceptible targets and be professed as active agents in the process of managing urban vulnerability [1,12]. Reinforcing Ruddell et al. argument that "it is critical to ground support for climate adaptation and mitigation initiatives within local contexts of shared experiences" [13], both local know-how and locally-driven design should always be considered as added value for adaptation endeavors. In addition, through a medium that is more accessible to people, climate change literacy may likely endorse an increased common need for action and the consequential pursuit of suitable solutions.

Good quality public spaces [14] particularly favor interdisciplinary design [9] and the embracement of multiple purposes [15]. In accordance, CABE Space (Commission for Architecture and the Built Environment), a leading advisor of the U.K. Design Council, argues that the adaptation of cities to climate-driven threats is strongly dependent on "well-designed, flexible public spaces" [16]. By combining flood adaptation measures with public space design, adjacent purposes arise more easily in other sectorial needs, such as water depuration, microclimatic melioration and/or social interaction enhancement. Moreover, in places founded through interdisciplinary means, the abovementioned "out-of-the-box" innovative thinking is more likely to emerge.

One may identify a wide range of current and past examples where a public space is combined together with one or more flood risk management measures. One may furthermore witness more recent examples where public spaces and flood risk management measures were explicitly integrated with climate change adaptation purposes [17]. The latter are encouraging and promoting new thinking, new solutions and, eventually, new paradigms [18]. However, there is still a considerable amount of unconnected information between the interrelated fields of adaptation knowledge. A particularly weak point is evidenced by the frail link between scientific findings and urban designers.

Although not as a focal issue, flood adaptation measures applied in the design of public spaces have been discussed by a range of diversified literature instances, namely scientific journals, books, research reports, conference proceedings and workshops. Particularly for those involved in the design of a public space that incorporates flood adaptation efforts, analyzing the existing knowledge is crucial. This notwithstanding, analyzing the existing knowledge must be done in a systematic way, otherwise it may still present unsatisfactory results when considering the time frame of one design proposal. In order to increase the rate of successful flood adaptation endeavors, fulfil municipal goals for more adaptive cities and diminish the gap between available knowledge and design processes, this paper aims to provide a conceptual framework of urban flood adaptation measures applicable to the design of public spaces.

\section{Methodology}

The goal to create a conceptual framework of urban flood adaptation measures applicable to the design of public spaces is essentially directed at assisting anyone involved in the process of designing a public space with the capacity to integrate flood adaptation responses. It is further based on the premise that it is not up to the investigator to decide what the best solution for a specific place is, but rather to enumerate, organize and characterize different possible solutions.

The framework's overall resulting output is therefore intended to be: (1) of a generic nature, yet capable of including an amplified range of alternatives; (2) simple in form and content, so that users find it easy to work and rationalize with; and (3) flexible to change in light of new arising information. The framework is further aspired to include a specific vocabulary that eliminates mainstreamed redundancies (i.e., different names given to the same type of measure) while adding new concepts emanating from contemporary designs.

The framework's construction is supported by two parallel tasks, whose findings endorse each other. As illustrated in Figure 1, these tasks comprise: (1) the classification of categories and types of flood adaptation measures applicable to the design of public spaces; and (2) a 'portfolio 
screening', corresponding to a database of examples. Both of these mentioned tasks are sustained by a comprehensive bibliographical review together with empirical observations (Figure 1).

Scientific, grey and technical literature review; data collection, data analysis, interviews with specialists, networking, site visits, empirical observations.

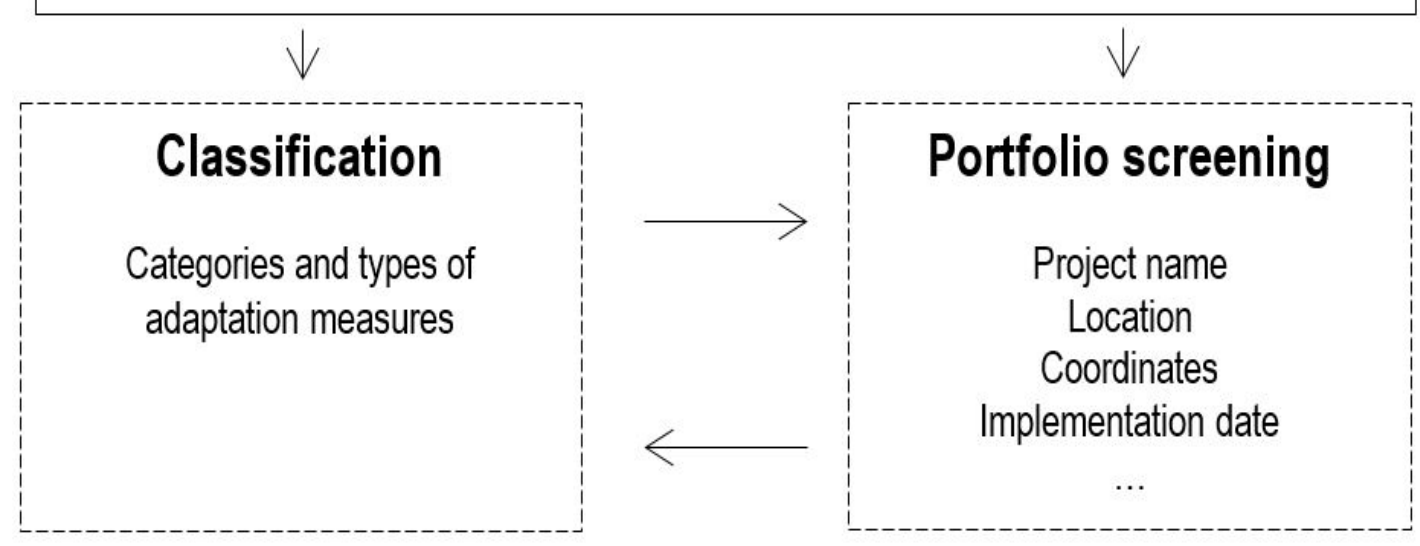

\section{Conceptual framework}

Figure 1. Methodological scheme for the framework's construction.

The classification analysis started off by identifying and analyzing the previously-developed research endeavors that proposed comprehensive frameworks, which included, or could be related to, climate change adaptation measures specifically related to urban flooding; in other words, flood risk management measures viewed through the lens of climate change projections.

According to the European Union's communication on "Flood Risk Management; Flood prevention, protection and mitigation", flood risk management aims to reduce the likelihood and/or the impact of floods. It further ascertains that flood risk management essentially comprises the strategies of 'prevention', 'protection', 'preparedness', 'emergency response' and 'recovery and lessons learned' [19]. In accordance, besides the non-structural measures, such as land use planning or evacuation planning, most of the identified comprehensive frameworks encompassed structural strategies and concomitant measures, which were not only related to urban stormwater systems (or urban drainage systems), such as sustainable drainage systems (SUDS), low impact development (LID), best management practices (BMPs), water sensitive urban design (WSUD) [20], but also those related to building design, flood defenses and embankment systems, among others [21].

Most of the identified comprehensive studies were related to R\&D projects and reports ordered by national or international governing entities, namely: Adaptation Planning, Research and Practice (WeADAPT) [22], UK Climate Impacts Programme (UKCIP) [23], Climate Adaptation Knowledge Exchange (CAKE) [24], European Climate Adaptation Platform (Climate-ADAPT) [25], Climate 'changes' Spatial Planning/Klimaat voor Ruimte (CcSP/KvR) [26], Adaptation and Mitigation: an Integrated Climate Policy Approach (AMICA) [27], ADaptation And Mitigation Strategies: supporting European climate policy (ADAM) [28], Green and Blue Space Adaptation for Urban Areas and Eco Towns (GRaBS) [29], The Climate Impacts: Global and Regional Adaptation Support Platform (ci:grasp) [30], European Spatial Planning: Adapting to Climate Events (ESPACE) [31], Towards an integrated decision tool for adaptation measures. Case study: floods (ADAPT) [32], Managing Water for the City of the Future (SWITCH) [33], Climate Adaptation: modelling water scenarios and sectorial 
impacts (ClimWatAdapt) [34], Foresight project on Flood and Coastal Defence (Foresight projects) [35], European Environmental Agency (EEA) [36-38], Climate Change adaptation by design: a guide for sustainable communities (Town and Country Planning Association (TCPA) Guide) [39] and Climate Impact Research \& Response Coordination for a Larger Europe (CIRCLE-2) [40].

These projects, which have an average duration of three years, generally comprise vast and multidisciplinary teams and often involve international collaborations. Recognizing the high probability of data obsolescence in light of contemporary frameworks (which, among others, entail "online sharing platforms" where knowledge in the form of case studies, reports and theses can be consulted or added to by anyone with Internet access), the developed literature overview is bounded by the year 2012. Envisioning the best possible result, significant contributions, such as empirical observations and further research findings, were also used in the framework's construction. Examples of these relevant inputs include the book River.Space.Design [41], the "Toolbox Adaptive Measures" (policopied document developed by Doepel Strijkers Architects) [42] or past know-how, such as the Greek cisterns and the street channels of Freiburg Bächle. Ultimately, adaptation to urban flooding will continue to promote the development of new relevant studies. Nonetheless, within the scope of this research, the corresponding findings started to deliver redundant results.

Besides the requirements to identify (1) flood-related climate change adaptation measures that are (2) applicable to the design of public spaces, the selection process from the findings of previously-developed frameworks followed the additional criteria (3) to be relevant to urban contexts and (4) include solely structural operational measures that is those which include technical design. This last criteria specifically aims to distinguish approaches that use design as a basic tool to face potential vulnerabilities, such as the ones associated with the projected increase of flood hazards. As a result, this separates the aforementioned criteria from those that are non-structural and more strategic, institutional, regulatory or political, such as forecasting, warning, information, evacuation, aid services, building codes or shared risk and compensations.

In Tables 1 and 2, outputs from nineteen studies, from R\&D projects to book publications with information available in English, Spanish or Portuguese, were collected and systematized. Subsequently, flood adaptation measures that could be applicable in the design of public spaces were specifically highlighted and simplified, compared and organized with the help of multiple spreadsheets. 
Table 1. Comprehensive frameworks that encompass measures related to urban flood adaptation: an overview (Part 1).

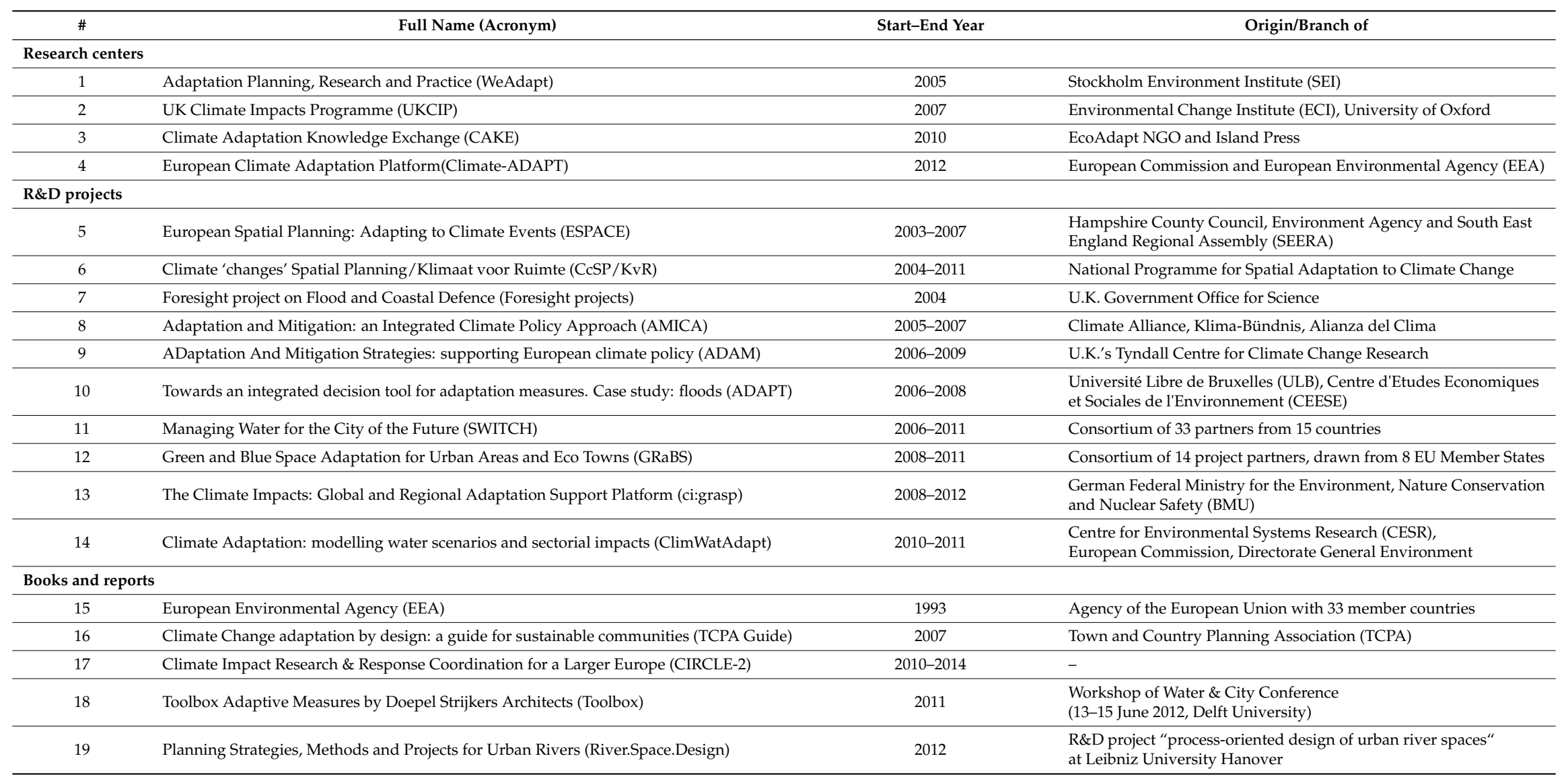


Table 2. Comprehensive frameworks that encompass measures related to urban flood adaptation: used deliverables (Part 2).

\begin{tabular}{|c|c|c|c|c|c|}
\hline \multirow{2}{*}{\multicolumn{2}{|c|}{ Acronym Name }} & \multicolumn{4}{|c|}{ Used Deliverable(s) } \\
\hline & & Name of Deliverable & Main Characteristics & Scale Extent & Scope \\
\hline \multicolumn{6}{|c|}{ Research centers } \\
\hline 1 & WeAdapt & Articles, Case studies and 'Adaptation Layer' & Online database and sharing platform & General & General \\
\hline 2 & UKCIP & Adaptation case studies, AdOpt & Online database, sharing platform and report (p. 34) & General (Europe) & General \\
\hline 3 & CAKE & Case Studies Database & Online database and sharing platform & General (USA) & General \\
\hline 4 & Climate-ADAPT & Adaptation support tool:database & Online database and sharing platform & Europe & General \\
\hline \multicolumn{6}{|c|}{ R\&D projects } \\
\hline 5 & ESPACE & SEERA toolkit (2005) & Report (p. 68) & General (case studies mostly U.K.) & Water management \\
\hline \multirow{2}{*}{6} & \multirow{2}{*}{ CcSP/KvR } & Final report COM11: Deltas on the move & Report (p. 97) & \multirow{2}{*}{ National (Netherlands) } & Water management \\
\hline & & Report A11, Routeplanner 2010-2050 & Report (p. 145) & & General \\
\hline 7 & Foresight projects & Future Flooding, Volume 2 (2007) & Report (p. 405) & National (U.K.) & Flooding \\
\hline 8 & AMICA & Adaptation Tool & Online database & General & General \\
\hline 9 & ADAM & Adam Digital Compendium, Adaptation Catalogue & Online database & Generic & General \\
\hline 10 & ADAPT & Final report (Phase I) & Report (p. 129) & General & Water management \\
\hline \multirow{2}{*}{11} & \multirow{2}{*}{ SWITCH } & Deliverable 5.1.5 & Report (p. 115) & General & \multirow{2}{*}{ Water managemen } \\
\hline & & Handbook Adapting urban water systems to climate change & Report (p. 53) & General & \\
\hline 12 & GRaBS & Adaptation Action Planning Toolkit & Online database & General & General \\
\hline 13 & ci: grasp & Adaptation project database & Online database and sharing platform & General & General \\
\hline 14 & ClimWatAdapt & Inventory of adaptation measures & Database & General & Water management \\
\hline \multicolumn{6}{|c|}{ Books and report } \\
\hline \multirow{3}{*}{15} & \multirow{3}{*}{ EEA } & Technical No. 2/2012 & Report (p. 143) & \multirow{3}{*}{ General } & General \\
\hline & & Technical No. 18/2011 & Report (p. 138) & & General \\
\hline & & EEA/ADS/06/001 & Report (p. 116) & & Water management \\
\hline 16 & TCPA Guide & - & Report (p. 49) & Generic (case studies from U.K.) & General \\
\hline 17 & Adaptation Inspiration Book (2013) & - & Book (p. 162) & Europe & General \\
\hline 18 & Toolbox Adaptive Measures & - & Policopied document & General & Flooding \\
\hline 19 & River.Space.Design & - & Book (p. 295) & Europe & $\begin{array}{l}\text { Urban river } \\
\text { landscapes }\end{array}$ \\
\hline
\end{tabular}


In parallel to the classification process based on the previously highlighted references, a database of examples was created. This database, here named 'portfolio screening' as a methodological approach, was conceived of with the main purpose to deduce and validate the identified adaptation measures through the matching with concrete public space design projects. It is a selection additionally focused on the attempt to unveil intellectual highlights from existing designs. It serves to emphasize conceptual findings with real case situations, as well as present added types of measures if not identified in the previously analyzed research studies.

The portfolio screening is not developed as an end itself and should not be considered comprehensive, but rather a significant sample of real-case situations that support and enrich the conceptual classification process. More concretely, it serves to show case examples that can be applicable to different contexts and with different purposes, hence providing further valuable information that may assist the decision-making throughout the design processes.

As evidenced in Table 3, there is at least one example for each type of identified measure, and some types of measures have up to six associated examples. The presented portfolio screening is based on comprehensive case studies highlighted in research projects, bibliographical reviews, interviews with specialists, networking and through site visits. The geographical breadth of the examples is limited by the facilitated access to information; an approach that does not compromise the general nature of the framework, due to the association with the aforementioned systematization in types and categories of measures.

Table 3. Identified flood adaptation categories and measures applicable to the design of urban public spaces, matched with existing examples.

\begin{tabular}{|c|c|c|c|c|c|}
\hline \multirow{2}{*}{ Category } & \multicolumn{2}{|c|}{ Measure } & \multirow{2}{*}{$\#$} & \multirow{2}{*}{ Project Name } & \multirow{2}{*}{ Location } \\
\hline & Label & Name & & & \\
\hline Urban greenery & a & Green walls & $\begin{array}{l}1 \\
2\end{array}$ & $\begin{array}{c}\text { Caixa Forum plaza } \\
\text { Westblaak' car park silo }\end{array}$ & $\begin{array}{l}\text { Madrid } \\
\text { Rotterdam }\end{array}$ \\
\hline \multirow[t]{2}{*}{$\begin{array}{l}\text { Urban } \\
\text { furniture }\end{array}$} & a & $\begin{array}{l}\text { Inverted } \\
\text { umbrellas }\end{array}$ & $\begin{array}{l}3 \\
4 \\
5\end{array}$ & $\begin{array}{c}\text { Woolworths Shopping playgr. } \\
\text { North Road } \\
\text { Expo Boulevard }\end{array}$ & $\begin{array}{l}\text { Walkerville } \\
\text { Preston } \\
\text { Shanghai }\end{array}$ \\
\hline & $\mathrm{b}$ & $\begin{array}{c}\text { Art } \\
\text { installations }\end{array}$ & 6 & Jawaharlal Planetarium Park & Karnataka \\
\hline \multirow[t]{2}{*}{$\begin{array}{l}\text { Rooftop } \\
\text { detention }\end{array}$} & a & Green roofs & $\begin{array}{c}7 \\
8 \\
9 \\
10 \\
11\end{array}$ & $\begin{array}{c}\text { Dakpark } \\
\text { Promenade Plantée } \\
\text { European Patent Office } \\
\text { Womans University } \\
\text { High Line Park }\end{array}$ & $\begin{array}{l}\text { Rotterdam } \\
\text { Paris } \\
\text { Rijswijk } \\
\text { Seoul } \\
\text { New York }\end{array}$ \\
\hline & $\mathrm{b}$ & Blue roofs & $\begin{array}{l}12 \\
13\end{array}$ & $\begin{array}{l}\text { Walter Bos Complex } \\
\text { Stephen Epler Hall }\end{array}$ & $\begin{array}{l}\text { Apeldoorn } \\
\text { Portland }\end{array}$ \\
\hline \multirow{4}{*}{ Reservoirs } & a & $\begin{array}{l}\text { Artificial } \\
\text { detention }\end{array}$ & $\begin{array}{l}14 \\
15\end{array}$ & $\begin{array}{l}\text { Parc de Diagonal Mar } \\
\text { Parc del Poblenou }\end{array}$ & $\begin{array}{l}\text { Barcelona } \\
\text { Barcelona }\end{array}$ \\
\hline & $\mathrm{b}$ & $\begin{array}{c}\text { basins } \\
\text { Water plazas }\end{array}$ & $\begin{array}{l}16 \\
17\end{array}$ & $\begin{array}{l}\text { Benthemplein square } \\
\text { Tanner Springs Park }\end{array}$ & $\begin{array}{l}\text { Rotterdam } \\
\text { Portland }\end{array}$ \\
\hline & c & $\begin{array}{l}\text { Underground } \\
\text { reservoirs }\end{array}$ & $\begin{array}{l}18 \\
19 \\
20 \\
21 \\
22\end{array}$ & $\begin{array}{c}\text { Parc de Joan Miró } \\
\text { Escola Industrial } \\
\text { Potsdamer Platz } \\
\text { Museumpark car park } \\
\text { Place Flagey }\end{array}$ & $\begin{array}{l}\text { Barcelona } \\
\text { Barcelona } \\
\text { Berlin } \\
\text { Rotterdam } \\
\text { Brussels }\end{array}$ \\
\hline & d & Cisterns & $\begin{array}{l}23 \\
24 \\
25\end{array}$ & $\begin{array}{l}\text { Stata Centre } \\
\text { The Circle } \\
\text { Georgia Street }\end{array}$ & $\begin{array}{l}\text { Massachusetts } \\
\text { Illinois } \\
\text { Indianapolis }\end{array}$ \\
\hline
\end{tabular}


Table 3. Cont.

\begin{tabular}{|c|c|c|c|c|c|}
\hline Category & \multicolumn{2}{|c|}{ Measure } & $\#$ & Project Name & Location \\
\hline \multirow{4}{*}{ Bioretention } & $\mathrm{a}$ & $\begin{array}{l}\text { Wet bioretention } \\
\text { basins }\end{array}$ & $\begin{array}{l}26 \\
27 \\
28\end{array}$ & $\begin{array}{c}\text { Parque Oeste } \\
\text { Qunli park } \\
\text { Emerald Necklace }\end{array}$ & $\begin{array}{l}\text { Lisbon } \\
\text { Haerbin } \\
\text { Boston }\end{array}$ \\
\hline & $\mathrm{b}$ & $\begin{array}{l}\text { Dry bioretention } \\
\text { basins }\end{array}$ & $\begin{array}{l}29 \\
30\end{array}$ & $\begin{array}{l}\text { Quinta da Granja } \\
\text { Parque da Cidade }\end{array}$ & $\begin{array}{l}\text { Lisbon } \\
\text { Porto }\end{array}$ \\
\hline & C & Bioswales & $\begin{array}{l}31 \\
32 \\
33 \\
34 \\
35 \\
36\end{array}$ & $\begin{array}{l}\text { Trabrennbahn Farmsen } \\
\text { Elmhurst parking lot } \\
\text { Ecocity Augustenborg } \\
\text { Museum of Science } \\
\text { High Point 30th Ave } \\
\text { Moor Park }\end{array}$ & $\begin{array}{c}\text { Hamburg } \\
\text { New York City } \\
\text { Malmö } \\
\text { Portland } \\
\text { Seattle } \\
\text { Blackpool }\end{array}$ \\
\hline & $\mathrm{e}$ & Rain gardens & $\begin{array}{l}42 \\
43 \\
44 \\
45\end{array}$ & $\begin{array}{c}\text { Edinburgh Gardens } \\
\text { Taasinge Square } \\
\text { Australia Road } \\
\text { East Liberty Town Square }\end{array}$ & $\begin{array}{l}\text { Melbourne } \\
\text { Copenhagen } \\
\text { London } \\
\text { Pittsburgh }\end{array}$ \\
\hline \multirow[b]{2}{*}{$\begin{array}{l}\text { Permeable } \\
\text { paving }\end{array}$} & $\mathrm{a}$ & Open cell pavers & $\begin{array}{l}46 \\
47 \\
\end{array}$ & $\begin{array}{c}\text { Can Caralleu } \\
\text { Zollhallen Plaza }\end{array}$ & $\begin{array}{l}\text { Barcelona } \\
\text { Freiburg }\end{array}$ \\
\hline & & Interlocking pavers & $\begin{array}{l}48 \\
49\end{array}$ & $\begin{array}{c}\text { Green park of Mondego } \\
\text { Bakery Square } 2.0\end{array}$ & $\begin{array}{c}\text { Coimbra } \\
\text { Pittsburgh }\end{array}$ \\
\hline \multirow{3}{*}{$\begin{array}{l}\text { Stream } \\
\text { recovery }\end{array}$} & $\mathrm{a}$ & Stream rehabilitation & $\begin{array}{l}56 \\
57 \\
58 \\
59 \\
60 \\
61\end{array}$ & $\begin{array}{c}\text { Rio Besòs River Park } \\
\text { Ribeira das Jardas } \\
\text { Ahna } \\
\text { River Volme } \\
\text { Promenada } \\
\text { Catharina Amalia Park }\end{array}$ & $\begin{array}{l}\text { Barcelona } \\
\text { Sintra } \\
\text { Kassel } \\
\text { Hagen } \\
\text { Velenje } \\
\text { Apeldoorn }\end{array}$ \\
\hline & $\mathrm{b}$ & Stream restoration & $\begin{array}{l}62 \\
63\end{array}$ & $\begin{array}{l}\text { Kallang River } \\
\text { Alb }\end{array}$ & $\begin{array}{l}\text { Bishan Park } \\
\text { Karlsruhe }\end{array}$ \\
\hline & C & Daylighting streams & $\begin{array}{l}64 \\
65 \\
66 \\
67\end{array}$ & $\begin{array}{c}\text { Westersingel } \\
\text { Thornton Creek } \\
\text { Cheonggyecheon River } \\
\text { Soestbach }\end{array}$ & $\begin{array}{l}\text { Rotterdam } \\
\text { Seattle } \\
\text { Seoul } \\
\text { Soest }\end{array}$ \\
\hline
\end{tabular}


Table 3. Cont.

\begin{tabular}{|c|c|c|c|c|c|}
\hline \multirow{2}{*}{ Category } & \multicolumn{2}{|c|}{ Measure } & \multirow{2}{*}{$\#$} & \multirow{2}{*}{ Project Name } & \multirow{2}{*}{ Location } \\
\hline & Label & Name & & & \\
\hline \multirow{9}{*}{$\begin{array}{l}\text { Open } \\
\text { drainage } \\
\text { systems }\end{array}$} & \multirow{4}{*}{$\mathrm{a}$} & \multirow{4}{*}{ Street channels } & 68 & Banyoles & Girona \\
\hline & & & 69 & Freiburg Bächle & Freiburg \\
\hline & & & 70 & Roombeek & Enschede \\
\hline & & & 71 & Solar City streets & Linz \\
\hline & \multirow{2}{*}{$\mathrm{b}$} & Extended channels & 72 & Pier Head & Liverpool \\
\hline & & Enlarged canals & 73 & Olympic park & London \\
\hline & \multirow{3}{*}{ c } & \multirow{3}{*}{ Check dams } & 74 & Kronsberg & Hannover \\
\hline & & & 75 & Renaissance Park & Tennessee \\
\hline & & & 76 & 21st Street & Paso Robles \\
\hline \multirow{6}{*}{$\begin{array}{l}\text { Floating } \\
\text { structures }\end{array}$} & \multirow{2}{*}{ a } & \multirow{2}{*}{ Floating pathway } & 77 & West India Quay & London \\
\hline & & & 78 & Ravelijn Bridge & $\begin{array}{l}\text { Bergen op } \\
\text { Zoom }\end{array}$ \\
\hline & \multirow[b]{2}{*}{$\mathrm{b}$} & \multirow{2}{*}{ Floating platform } & 79 & Yongning River Park & Taizhou \\
\hline & & & 80 & Landungsbrücken pier & Hamburg \\
\hline & \multirow{2}{*}{ c } & \multirow{2}{*}{ Floating islands } & 81 & Spree Bathing Ship & Berlin \\
\hline & & & 82 & Leine Suite & Hannover \\
\hline \multirow{7}{*}{ Wet-proof } & \multirow{5}{*}{ a } & \multirow{5}{*}{ Submergible parks } & 83 & Rhone River Banks & Lyon \\
\hline & & & 84 & Parque fluvial del Gallego & Zuera \\
\hline & & & 85 & Buffalo Bayou Park & Houston \\
\hline & & & 86 & Parc de la Seille & Metz \\
\hline & & & 87 & Park Van Luna & Heerhugowaard \\
\hline & \multirow{2}{*}{$\mathrm{b}$} & \multirow{2}{*}{$\begin{array}{c}\text { Submergible } \\
\text { pathways }\end{array}$} & 88 & Passeio Atlântico & Porto \\
\hline & & & 89 & Quai des Gondoles & Choisy-le-Roi \\
\hline \multirow{3}{*}{$\begin{array}{c}\text { Raised } \\
\text { structures }\end{array}$} & \multirow{2}{*}{ a } & \multirow{2}{*}{$\begin{array}{c}\text { Cantilevered } \\
\text { pathways }\end{array}$} & 90 & Elster and Pleiße Millraces & Leipzig \\
\hline & & & 91 & Terreiro do Rato & Covilhã \\
\hline & $\mathrm{b}$ & $\begin{array}{c}\text { Elevated } \\
\text { promenades }\end{array}$ & 92 & Waterfront promenade & Bilbao \\
\hline & & Multifunctional & 93 & Elbe promenade & Hamburg \\
\hline & a & defenses & 94 & Dike of 'Boompjes' & Rotterdam \\
\hline & & & 95 & Zona de Banys del Fòrum & Barcelona \\
\hline Coastal & $\mathrm{b}$ & Breakwaters & 96 & Molhe da Barra do Douro & Porto \\
\hline & & & 97 & Jack Evans Harbour & Tweed Heads \\
\hline & & & 98 & Schevenigen & The Hauge \\
\hline & c & Embankments & 99 & Blackpool Seafront & Blackpool \\
\hline & & & 100 & Sea organ & Zadar \\
\hline Floodwalls & a & Sculptured walls & 101 & Main riverside & Miltenberg \\
\hline t8 & $\mathrm{b}$ & Glass walls & 102 & Westhoven & Cologne \\
\hline & & Demountable & 103 & Wallkade promenade & Zaltbommel \\
\hline Barriers & a & barriers & 104 & Landungsbrücken building & Hamburg \\
\hline Levees & a & Gentle slope levees & 105 & Corktown Common & Toronto \\
\hline
\end{tabular}

\section{Results: Proposed Conceptual Framework}

In light of the constructed database of categories and types of flood adaptation measures applicable to public space design as presented in Table 3, various frameworks can be proposed. In other words, the identified categories and types of measures can be differently organized in accordance with diverse and particular purposes or contexts. The range of possible organizations is as wide as the potentially numerous analysis of the identified types of measures and its corresponding examples.

Among the possible analyses are the resulting classifications in light of the following questions: for which type of flood is the measure most appropriate (pluvial, fluvial, groundwater, artificial drainage, coastal)? To which infrastructural strategy does the measure primarily relate to (harvest, store, infiltrate, convey, tolerate, avoid)? In what areas of the watershed are the measures applicable? What is the 
physical extent of the benefits provided by each measure (on-site; downstream, upstream, off-stream)? What is the estimated scale of the investments (building, neighborhood, small town, urban regional)? What are the estimated costs associated with each measure? In what type of public space can each measure be applied (layout spaces, landscape spaces, itinerating spaces, memory spaces, commerce spaces, generated spaces); or even in circumstances that call for a comparative analysis between different measures, such as the contrast between 'artificial', 'hard' engineering measures and 'soft', 'natural' measures? Other analysis can dwell, among others, upon the infrastructural efficiency of each measure, namely regarding water accumulation (large, small, how much) or into further distinctions among 'win-win', 'no-regrets', 'low'-regrets (or limited-regrets) or 'flexible adaptation' strategies.

Each classification is to be primarily based on the analysis of the gathered existing examples. As illustrated in Table 4, examples may be analyzed regarding diverse aspects. For instance, in Measure 2, Examples 1 and 2 are solely related to Flood Type 2. As a result, it is concluded that Measure 2 is mostly related to a specific type of flood, i.e., Type 2. Following this line of reasoning a little further, all three examples of Measure 1 do not encompass Infrastructural Strategy 3. As such, Measure 1 entails Infrastructural Strategies 1, 2 and 4 and not 3. The classifications are made through empirical observations and a literature review related to each specific example, both underpinned by the state of the art review regarding the subject of analysis (type of flood, infrastructural strategy, physical extent of benefits, scale of investment, area of the watershed, among others).

Table 4. Illustrative diagram of the classification process carried out for each analyzed subject (type of flood, infrastructural strategy, physical extent of benefits, among others).

\begin{tabular}{|c|c|c|c|c|c|c|c|c|c|c|c|c|}
\hline \multirow{2}{*}{ Category } & \multirow{2}{*}{ Measure } & \multirow{2}{*}{ Example } & \multicolumn{5}{|c|}{ Type of Flood } & \multicolumn{4}{|c|}{ Physical Extent of Benefits } & \multirow{2}{*}{$\frac{\ldots *}{\ldots}$} \\
\hline & & & 1 & 2 & 3 & 4 & 5 & 1 & 2 & 3 & 4 & \\
\hline \multirow{5}{*}{ Category 1} & \multirow{3}{*}{ Measure 1} & e.g., 1 & $x$ & - & - & $x$ & - & - & - & $x$ & - & $\ldots$ \\
\hline & & e.g., 2 & - & $x$ & $x$ & $x$ & - & $x$ & - & $X$ & - & $\ldots$ \\
\hline & & e.g., 3 & - & $x$ & $x$ & - & - & - & $x$ & - & - & $\ldots$ \\
\hline & \multirow{2}{*}{ Measure 2} & e.g., 1 & - & $x$ & $x$ & - & - & $x$ & - & - & - & $\ldots$ \\
\hline & & e.g., 2 & - & $x$ & $x$ & - & $x$ & $x$ & - & - & - & $\ldots$ \\
\hline
\end{tabular}

Note: ${ }^{*}$ Each example may be analyzed regarding several further aspects.

Results must be revisited in light of new examples or new information about each concrete situation. Moreover, most analyses lead to multiple classifications. For example, among the identified types of measures, some may be particularly associated with one specific infrastructural strategy, while others may relate to more than one strategy. More specifically, for instance, in addition to storing water, 'bioretention basins' potentially contribute to the strategies of harvest, infiltrate, convey and tolerate. Contrastingly, 'underground regulation reservoirs' potentially serve the infrastructural store, harvest, convey and tolerate strategies.

Contributing to the complexity of the disclosed assessment, all of the proposed questions and provided classifications are intimately interlinked. One can namely highlight how the type of flood generally dictates the most commonly chosen infrastructural strategy. More distinctly, pluvial floods are generally tackled with the infrastructural strategies of 'harvest', 'store', 'infiltrate' and 'convey'; fluvial floods are generally approached with strategies of 'convey', 'tolerate' and 'avoid'; coastal floods are usually tackled with the strategies of 'tolerate' and 'avoid'; groundwater floods are mostly tackled with the strategies of 'convey' and 'tolerate'; and artificial drainage flooding is commonly tackled with the strategies of 'store', 'convey' and 'tolerate'. Yet one must bear in mind that, although some measures may be particularly adequate to face a certain type of flood, they may also provide complementary benefits to the adaptation to other types of floods by comparison. For instance, the benefits provided by green roofs (which can be particularly useful for the purported groundwater floods once they can 'harvest' water before it reaches the ground) are wide-ranging and can also be considered as beneficial to the reduction of both the frequency and intensity of pluvial floods. 
The associated implementation costs also naturally influence the process of choosing the adequate measure or range of measures. While some measures may be significantly more costly than others, they may prove to be more efficient in light of a particular infrastructural strategy. 'Multifunctional defenses', for example, regardless of their high costs, may be considered as particularly adequate for an area that has already been severely affected by intense storm surges and advocates the 'avoid' strategy. For the same situation, yet in light of other infrastructural strategies, other measures may be applied, such as 'wet-proof parks' or 'floating structures' related to the 'tolerate' approach. Although they are less efficient in comparison to the strategy of 'avoid', these measures particularly targeted at tolerating stormwater comprise additional parallel benefits that should not be underestimated, including a better adaptive capacity for a much wider timeframe. A similar association can be made when generally comparing 'artificial' and 'hard' engineering measures with more 'soft', 'natural' measures. Whereas the first may be particularly efficient in solving intense flood hazards in a relatively short period of time, natural solutions require extensive implementations and longer timeframes. On the other hand, these solutions have the added value of contributing significantly to the overall quality of water bodies and of the urban environment [43]. When a measure is characterized by not being very costly, and by not worsening the initial situation even when it does not work as expected, it can be identified as a 'safe-to-fail' measure [44]. This is namely the case of the previously mentioned 'green roofs'. They are fairly inexpensive measures that even if not fulfilling the flood risk management purpose of water harvesting, they may fulfil other purposes, such as improving microclimatic conditions by permitting increased albedo levels or encouraging evapotranspiration processes [45]. These types of measures are particularly interesting in the context of learning and exploring adaptation processes, since they are not hindered by the need to succeed and consequently endorse continual improvement [46]. Contrastingly, the malfunctioning of an underground regulation reservoir, even when disregarding the costs associated with its construction, may lead to increased flood occurrences and the aggravation of the initial situation, namely by being an added obstruction to the flow of underground water.

\subsection{Assessment by Flood Adaptation Infrastructural Strategies}

Amongst the above-mentioned alternatives to assess the identified types of measures, it was chosen to deepen the framework's construction and to organize its structure in light of flood adaptation infrastructural strategies. Each measure was therefore associated with one main and/or one or more secondary infrastructural purpose. Several concepts describe various possible infrastructural strategies, yet the following comprehensive group is here proposed: harvest, store, infiltrate, convey, tolerate and avoid (Table 5 and Figures 2-7).

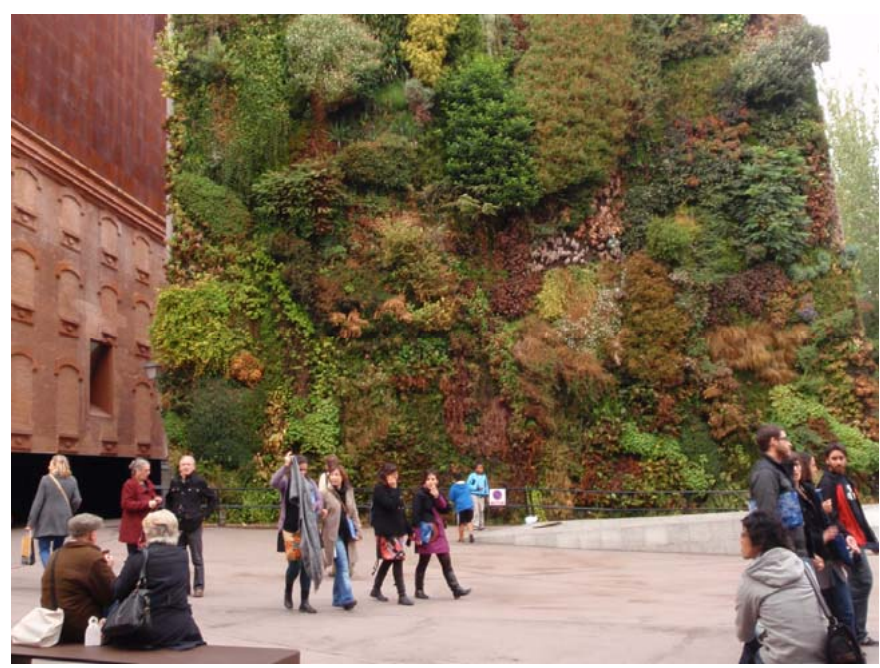

Figure 2. Green facade at the Caixa forum plaza, Madrid, Spain. Image credits: Maria Matos Silva, 2011. 


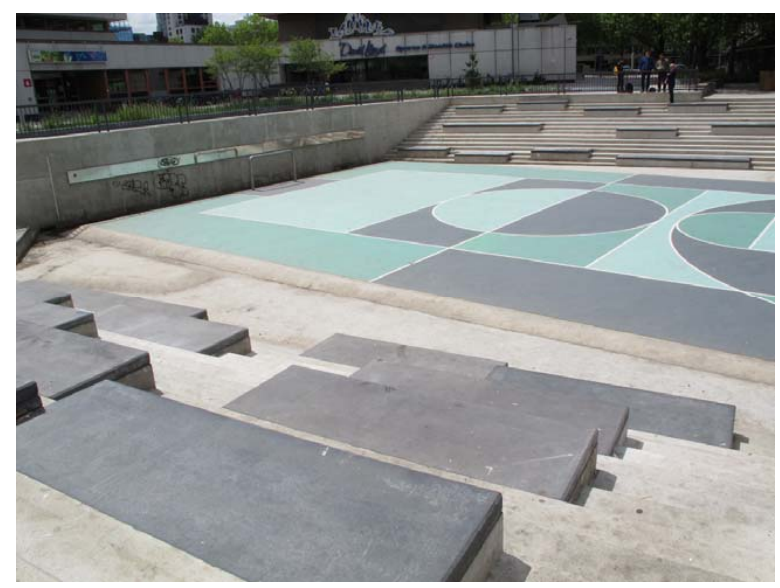

Figure 3. Water plaza at Benthemplein, Rotterdam, The Netherlands. Image credits: Maria Matos Silva, 2014.

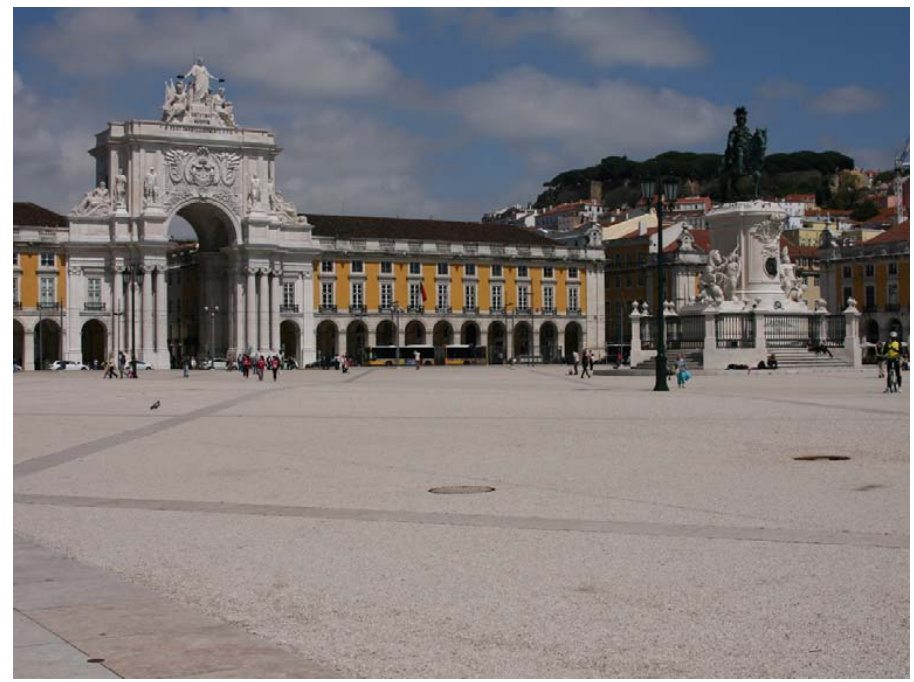

Figure 4. Permeable pavement composed of limestone gravel and a colorless synthetic binder at Terreiro do Paço, Lisboa, Portugal. Image credits: Maria Matos Silva, 2014.

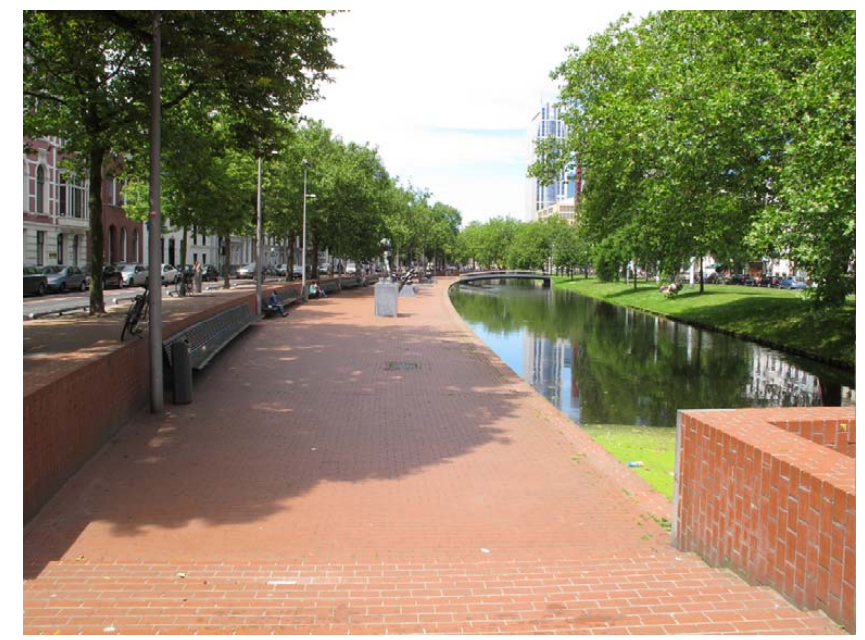

Figure 5. Daylit Westersingel channel at Rotterdam, The Netherlands. Image credits: Maria Matos Silva, 2014. 


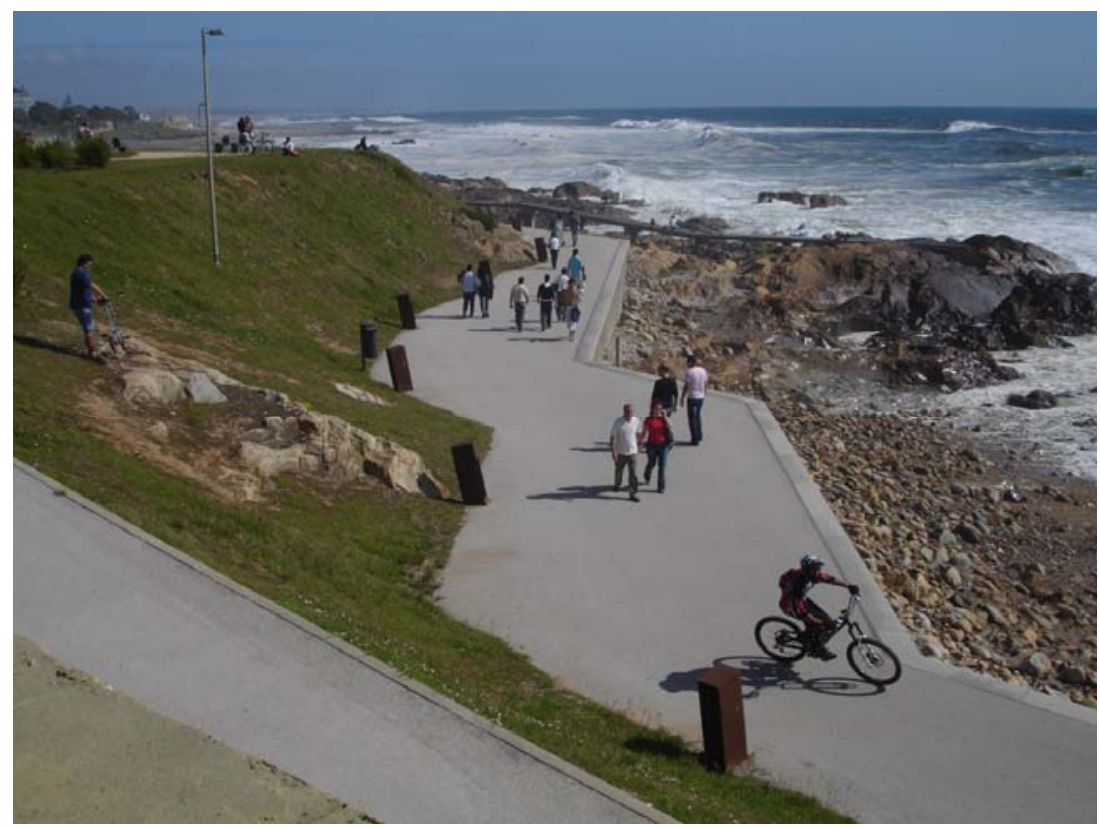

Figure 6. Detail of a submergible pathway that uses strong and resistant materials. More specifically Passeio Atlântico at Porto, Portugal. Image credits: Maria Matos Silva, 2007.

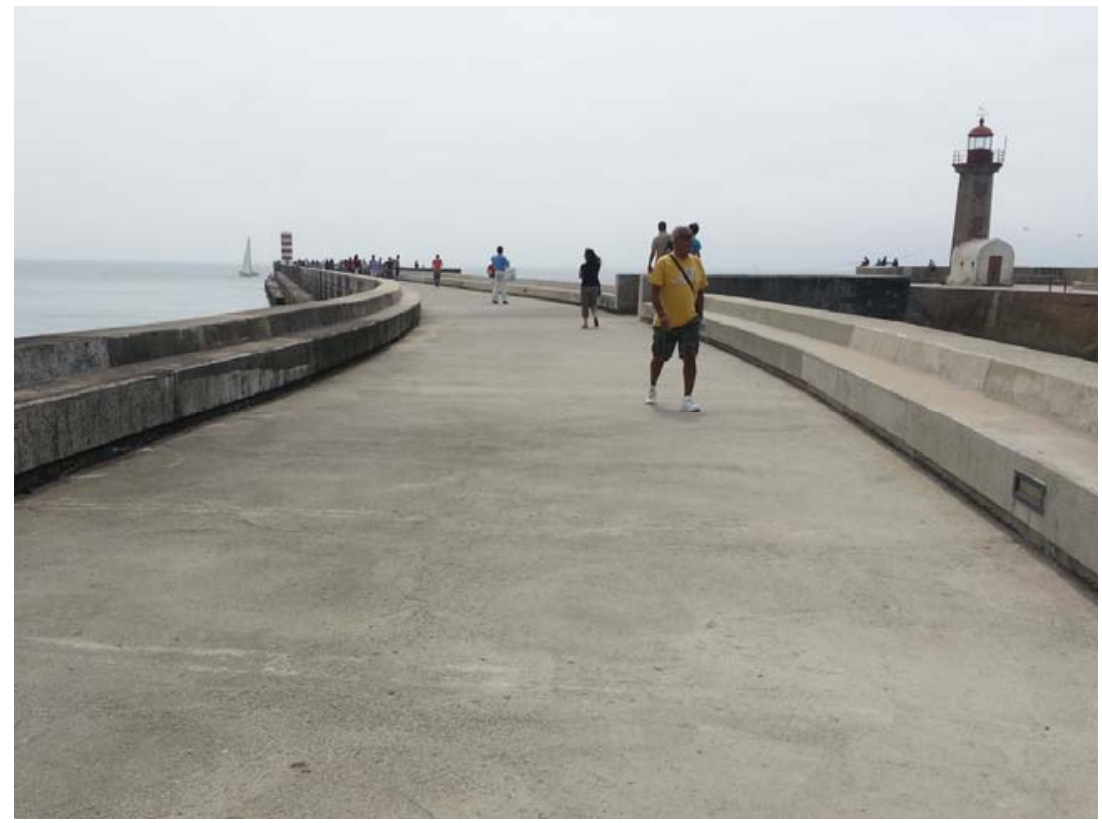

Figure 7. Detail of "Molhe da Barra do Douro", the first south bank Douro pier at Porto, Portugal. Image credits: Maria Matos Silva, 2013. 
Table 5. Proposed range of flood adaptation infrastructural strategies, each with a summarized description.

\begin{tabular}{|c|c|}
\hline $\begin{array}{l}\text { Harvest } \\
\downarrow\end{array}$ & $\begin{array}{l}\text { Measures that relate to the infrastructural strategy of 'harvest' can be generally characterized by their capacity to catch and collect rainwater } \\
\text { before contributing to stormwater runoff. Collected rainwater can replace or supplement treated water of potable quality, thus contributing to the } \\
\text { reduction of a city's demand for water supply. It can further extend supplies from regional reservoirs and restore environmental flows in rivers used } \\
\text { for water supply [47]. It is therefore a particularly interesting infrastructural strategy to be applied in urban situations of water scarcity. It is also an } \\
\text { especially attractive infrastructural strategy to face groundwater floods, since rainwater harvesting in upstream catchments can decrease } \\
\text { stormwater-driven peak flows and overloads in drainage infrastructure [48]. } \\
\text { Harvesting measures can range noticeably in scale and complexity from a single urban fixture to a green wall (Figure 2), such as inverted umbrellas or } \\
\text { a community system of green roofs. For example, at Potsdamer Platz in Berlin, a total of } 32.000 \mathrm{~m}^{2} \text { of roof collects } 21 \text { inches (around } 0.5 \mathrm{~m} \text { ) of annual } \\
\text { rainfall and stores it in a } 3.500 \mathrm{~m}^{3} \text { tank (UNEP } 2011 \text { in [49]). }\end{array}$ \\
\hline $\begin{array}{c}\text { Store } \\
\stackrel{5}{\longrightarrow}\end{array}$ & $\begin{array}{l}\text { Measures that entail the infrastructural capacity to 'store' water also contribute to the minimization of overall urban runoff and pressure } \\
\text { alleviation upon existing infrastructural systems. This type of measure can be designed to store water either above or belowground. When comprised } \\
\text { with appropriate vegetation and depending on the design detention time, stored water can be additionally filtered and purified, thus potentially } \\
\text { providing water with improved quality. It has been further evidenced that rainwater collected from roofs improves its quality by storage in tanks [50]. } \\
\text { Measures with the capacity to store water also vary in scale and complexity. Raingardens or bioswales are relatively small and straightforwardly } \\
\text { implemented when compared to wet bioretention basins or regulation reservoirs. Although compact urban territories are unlikely to have the } \\
\text { available space for the implementation of larger-scale measures, alternatives exist in order to store water in densely-urbanized areas. An exemplary } \\
\text { case regarding the formerly mentioned situation is the water plaza at Rotterdam in the Netherlands, designed by De Urbanisten office (Figure } 3 \text { ). The } \\
\text { total surface area encompassed within this project is } 9.500 \mathrm{~m}^{2} \text {, including street and parking. The actual water square has an area of } 5.500 \mathrm{~m}^{2} \text { and offers } \\
1.800 \mathrm{~m}^{3} \text { of temporal water storage [51]. }\end{array}$ \\
\hline Infiltrate & $\begin{array}{l}\text { Measures that encompass the flood adaptation infrastructural strategy to 'infiltrate' stormwater include trenches, basins or permeable pavements } \\
\text { that enhance the intrusion of water into subsoil layers or into other types of storage or conveyance measures. The porous paving illustrated in Figure } 4 \text {, } \\
\text { for example, composed of limestone gravel and stone dust compressed with a colorless synthetic binder, drains stormwater into the underneath } \\
\text { drainage system. } \\
\text { Measures primarily targeted at the infrastructural strategy to 'infiltrate' generally entail filtration mediums, such as gravel and rock, which treat } \\
\text { stormwater and lead it into substratal soils. Yet, the particular function to infiltrate into subsoil layers is more effective when measures are combined } \\
\text { with other measures specifically related to the functions of harvest or store in order to effectively pre-treat stormwater [52]. Through correctly } \\
\text { implemented infiltration processes, it is therefore not only possible to remove a great range of pollutants, such as suspended solids or heavy metals, } \\
\text { but also to promote the recharge of groundwater aquifers and, thus, support water supply sources [53]. } \\
\text { In similarity to storage measures, infiltration measures may therefore also substantially reduce runoff volumes. For example, the infiltration trench } \\
\text { implemented below Elmer Avenue is capable of capturing 750,000 gallons of runoff [54]. }\end{array}$ \\
\hline
\end{tabular}


Table 5. Cont

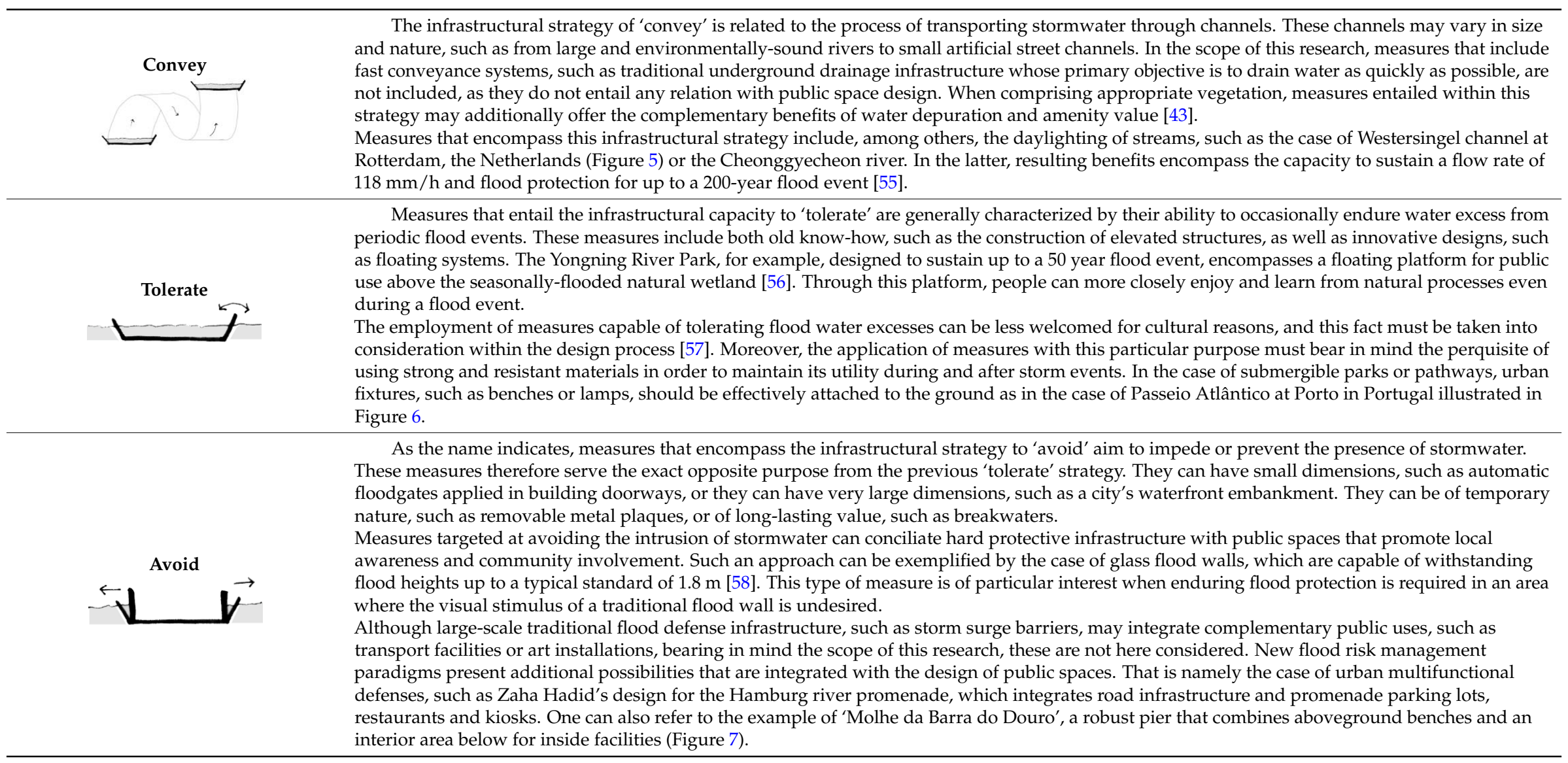


The option to emphasize the measure's infrastructural capacities is essentially related to the conducted methodological approach that primarily envisioned the proposition of a conceptual framework of prompt utility. By organizing measures by their infrastructural strategies, the framework's practical use is directly evidenced. Another motive is related to the needed and fundamental integration with the few established leading disciplines in the solving of problems associated with urban flooding. By approaching the matter with commonly-used vocabulary and similar technical notions, the communication and exchange of know-how are facilitated.

Regardless of not being included in the proposed encompassing set of infrastructural strategies, it is important to highlight that 'source control' is one other commonly-used concept, which entails a particular infrastructural approach. As the name indicates, this infrastructural strategy aims to tackle floods in its source, namely though harvest, store and infiltration measures.

In line with the descriptions presented in Table 5, which are underpinned by the previously mentioned analyzed frameworks presented in Tables 1 and 2, the proposed analysis was specifically made considering each identified example. Each classification is based on empirical observations, as well as bibliographical information regarding each specific public space project. As displayed in Table 6, each exemplar is associated with a primary infrastructural strategy (identified with a bold $\mathbf{X}$ ) and, if recognized, one or more secondary infrastructural strategies (identified with a plain X). For example, the wet bioretention basin of Parque Oeste in Lisbon (\#26) encompasses all of the infrastructural strategies, except 'avoid', while the Escola Industrial sports field (\#19), comprising an underground reservoir, solely includes the infrastructural strategies of 'store' and 'tolerate'.

Table 6. Classification of the primary and secondary infrastructural strategies encompassed in each presented example.

\begin{tabular}{|c|c|c|c|c|c|c|c|}
\hline \multirow{2}{*}{$\frac{\text { Number }}{\#}$} & \multirow{2}{*}{$\begin{array}{c}\text { Examples } \\
\text { Project Name }\end{array}$} & \multicolumn{6}{|c|}{ Infrastructural Strategy } \\
\hline & & Harvest & Store & Infiltrate & Convey & Tolerate & Avoid \\
\hline 1 & Caixa Forum plaza & $x$ & $x$ & $x$ & - & - & - \\
\hline 2 & Westblaak' car park silo & $X$ & $x$ & - & - & - & - \\
\hline 3 & Woolworths Shopping playgr. & $x$ & $x$ & - & - & - & - \\
\hline 4 & North Road & $X$ & $x$ & - & - & - & - \\
\hline 5 & Expo Boulevard & $\mathbf{X}$ & $x$ & - & - & - & - \\
\hline 6 & Jawaharlal Planetarium Park & $x$ & $x$ & - & - & - & - \\
\hline 7 & Dakpark & $x$ & $x$ & $x$ & - & - & - \\
\hline 8 & Promenade Plantée & $x$ & $x$ & - & - & - & - \\
\hline 9 & European Patent Office & $X$ & $x$ & - & - & - & - \\
\hline 10 & Womans University & $x$ & $x$ & $x$ & - & - & - \\
\hline 11 & High Line Park & $X$ & $x$ & $x$ & - & - & - \\
\hline 12 & Walter Bos Complex & $\mathbf{x}$ & $x$ & - & - & - & - \\
\hline 13 & Stephen Epler Hall & $x$ & $x$ & - & - & - & - \\
\hline 14 & Parc de Diagonal Mar & - & $x$ & - & - & $x$ & - \\
\hline 15 & Parc del Poblenou & - & $x$ & - & - & $x$ & - \\
\hline 16 & Benthemplein square & $x$ & $X$ & - & - & $x$ & - \\
\hline 17 & Tanner Springs Park & $x$ & $X$ & - & - & $x$ & - \\
\hline 18 & Parc de Joan Miró & $x$ & $x$ & - & - & - & - \\
\hline 19 & Escola Industrial & - & 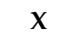 & - & - & $x$ & - \\
\hline 20 & Potsdamer Platz & $x$ & $x$ & - & $x$ & - & - \\
\hline 21 & Museumpark car park & - & $X$ & - & - & $x$ & - \\
\hline 22 & Place Flagey & - & $X$ & - & - & $x$ & - \\
\hline 23 & Stata Center & - & $x$ & $x$ & - & - & - \\
\hline 24 & The Circle & $x$ & $x$ & - & - & - & - \\
\hline 25 & Georgia Street & - & $x$ & $x$ & $x$ & - & - \\
\hline 26 & Parque Oeste & $x$ & $x$ & $x$ & $x$ & $x$ & - \\
\hline 27 & Qunli park & $x$ & $x$ & $x$ & - & $x$ & - \\
\hline 28 & Emerald Necklace & $x$ & $X$ & $x$ & $x$ & $x$ & - \\
\hline 29 & Quinta da Granja & $x$ & $\mathbf{X}$ & $x$ & - & $x$ & - \\
\hline 30 & Parque da Cidade & $x$ & $X$ & $x$ & $x$ & $x$ & - \\
\hline 31 & Trabrennbahn Farmsen & $x$ & $x$ & $x$ & $x$ & - & - \\
\hline 32 & Elmhurst parking lot & $x$ & $x$ & $x$ & $x$ & - & - \\
\hline 33 & Ecocity Augustenborg & $x$ & $\mathbf{X}$ & $x$ & $x$ & - & - \\
\hline 34 & Museum of Science & $x$ & $X$ & $x$ & $x$ & - & - \\
\hline 35 & High Point 30th Ave & $x$ & $X$ & $x$ & $x$ & - & - \\
\hline 36 & Moor Park & $x$ & $X$ & $x$ & $x$ & - & - \\
\hline 37 & Ribblesdale Road & $x$ & $X$ & $x$ & $x$ & - & - \\
\hline
\end{tabular}


Table 6. Cont

\begin{tabular}{|c|c|c|c|c|c|c|c|}
\hline \multirow{2}{*}{$\begin{array}{c}\text { Number } \\
\#\end{array}$} & \multirow{2}{*}{$\begin{array}{c}\text { Examples } \\
\text { Project Name }\end{array}$} & \multicolumn{6}{|c|}{ Infrastructural Strategy } \\
\hline & & Harvest & Store & Infiltrate & Convey & Tolerate & Avoid \\
\hline 38 & South Australian Museum & $x$ & $x$ & $x$ & - & - & - \\
\hline 39 & Columbus Square & $\mathrm{x}$ & $\mathrm{x}$ & $\mathrm{x}$ & $\mathrm{x}$ & - & - \\
\hline 40 & Derbyshire Street & $\mathrm{x}$ & $\mathrm{x}$ & $x$ & $x$ & - & - \\
\hline 41 & Onondaga County & $\mathrm{x}$ & $\mathrm{x}$ & $x$ & $\mathrm{x}$ & - & - \\
\hline 42 & Edinburgh Gardens & $x$ & $\mathrm{x}$ & $x$ & - & $\mathrm{x}$ & - \\
\hline 43 & Taasinge Square & $\mathrm{x}$ & $\mathrm{x}$ & $\mathrm{x}$ & - & $\mathrm{X}$ & - \\
\hline 44 & Australia Road & $\mathrm{x}$ & $\mathrm{x}$ & $\mathrm{x}$ & _- & $\mathrm{x}$ & _- \\
\hline 45 & East Liberty Town Square & $\mathrm{x}$ & $\mathrm{x}$ & $\mathrm{x}$ & - & - & - \\
\hline 46 & Can Caralleu & $\mathrm{x}$ & $\mathrm{x}$ & $\mathrm{x}$ & - & - & - \\
\hline 47 & Zollhallen Plaza & $\mathrm{x}$ & $\mathrm{x}$ & $x$ & - & $x$ & - \\
\hline 48 & Green park of Mondego & $\mathrm{x}$ & $\mathrm{x}$ & $\mathrm{x}$ & - & $x$ & - \\
\hline 49 & Bakery Square 2.0 & $\mathrm{x}$ & $\mathrm{x}$ & $\mathrm{x}$ & $\mathrm{x}$ & $\mathrm{x}$ & - \\
\hline 50 & Praça do Comércio & - & $\mathrm{x}$ & $\mathrm{x}$ & - & $x$ & - \\
\hline 51 & Percy Street & - & $x$ & $\mathrm{x}$ & - & $x$ & - \\
\hline 52 & Greenfield Elementary & - & $\mathrm{x}$ & $x$ & - & $x$ & - \\
\hline 53 & Etna Butler Street & - & $\mathrm{x}$ & $\mathrm{x}$ & - & - & - \\
\hline 54 & Community College & - & $\mathrm{x}$ & $\mathrm{x}$ & - & - & - \\
\hline 55 & Elmer Avenue Neighborhood & - & $\mathrm{x}$ & $\mathrm{x}$ & $x$ & - & - \\
\hline 56 & Rio Besòs River Park & $\mathrm{x}$ & $\mathrm{x}$ & $\mathrm{x}$ & $\mathrm{x}$ & $\mathrm{x}$ & _- \\
\hline 57 & Ribeira das Jardas & $\mathrm{x}$ & $\mathrm{x}$ & $\mathrm{x}$ & $\mathrm{x}$ & $\mathrm{x}$ & - \\
\hline 58 & Ahna & $\mathrm{x}$ & $\mathrm{x}$ & - & $\mathrm{x}$ & - & - \\
\hline 59 & River Volme & - & $x$ & - & $\mathrm{x}$ & - & - \\
\hline 60 & Promenada & - & - & - & $\mathrm{X}$ & $\mathrm{x}$ & - \\
\hline 61 & Catharina Amalia Park & $\mathrm{x}$ & $\mathrm{x}$ & $x$ & $\mathrm{x}$ & $x$ & _- \\
\hline 62 & Kallang River & $\mathrm{x}$ & $\mathrm{x}$ & $\mathrm{X}$ & $\mathrm{X}$ & $\mathrm{x}$ & - \\
\hline 63 & Alb & $\mathrm{x}$ & $\mathrm{x}$ & $\mathrm{x}$ & $\mathrm{x}$ & $\mathrm{x}$ & - \\
\hline 64 & Westersingel & $\mathrm{x}$ & $\mathrm{x}$ & $\mathrm{x}$ & $\mathrm{x}$ & $\mathrm{x}$ & - \\
\hline 65 & Thornton Creek & $\mathrm{x}$ & $\mathrm{x}$ & $\mathrm{x}$ & $\mathrm{X}$ & $x$ & - \\
\hline 66 & Cheonggyecheon River & $\mathrm{x}$ & $\mathrm{x}$ & $\mathrm{x}$ & $\mathrm{x}$ & $\mathrm{x}$ & - \\
\hline 67 & Soestbach & - & $\mathrm{x}$ & - & $\mathrm{x}$ & - & - \\
\hline 68 & Banyoles & - & $x$ & - & $\mathrm{X}$ & $\mathrm{x}$ & - \\
\hline 69 & Freiburg Bächle & - & $\mathrm{x}$ & - & $\mathrm{X}$ & $x$ & - \\
\hline 70 & Roombeek & $\mathrm{x}$ & $\mathrm{x}$ & - & $\mathrm{x}$ & - & - \\
\hline 71 & Solar City streets & - & $\mathrm{x}$ & - & $\mathrm{x}$ & - & - \\
\hline 72 & Pier Head & - & $\mathrm{x}$ & - & $\mathrm{X}$ & $x$ & - \\
\hline 73 & Olympic park & $\mathrm{x}$ & $\mathrm{x}$ & $x$ & $\mathrm{x}$ & $x$ & - \\
\hline 74 & Kronsberg & $\mathrm{x}$ & $\mathrm{x}$ & $\mathrm{X}$ & $\mathrm{x}$ & $\mathrm{x}$ & - \\
\hline 75 & Renaissance Park & $\mathrm{x}$ & $\mathrm{x}$ & - & $\mathrm{x}$ & $\mathrm{x}$ & - \\
\hline 76 & 21st Street & $x$ & $\mathrm{x}$ & $x$ & $\mathrm{X}$ & $x$ & - \\
\hline 77 & West India Quay & - & - & - & - & $\mathrm{x}$ & - \\
\hline 78 & Ravelijn Bridge & _- & - & - & - & $\mathrm{x}$ & _- \\
\hline 79 & Yongning River Park & $\mathrm{x}$ & - & - & - & $\mathrm{X}$ & - \\
\hline 80 & Landungsbrücken pier & - & - & - & - & $\mathrm{x}$ & - \\
\hline 81 & Spree Bathing Ship & - & $\mathrm{x}$ & - & - & $\mathrm{x}$ & - \\
\hline 82 & Leine Suite & - & - & - & - & $\mathrm{X}$ & - \\
\hline 83 & Rhone River Banks & $\mathrm{x}$ & $\mathrm{x}$ & $x$ & $\mathrm{x}$ & $\mathrm{x}$ & - \\
\hline 84 & Parque fluvial del Gallego & $\mathrm{x}$ & $\mathrm{x}$ & $\mathrm{x}$ & $\mathrm{x}$ & $\mathrm{x}$ & _- \\
\hline 85 & Buffalo Bayou Park & $\mathrm{x}$ & $\mathrm{x}$ & $\mathrm{x}$ & $\mathrm{x}$ & $\mathrm{x}$ & - \\
\hline 86 & Parc de la Seille & $\mathrm{x}$ & $\mathrm{x}$ & $x$ & $\mathrm{x}$ & $\mathrm{x}$ & - \\
\hline 87 & Park Van Luna & $\mathrm{x}$ & $\mathrm{x}$ & - & $\mathrm{x}$ & $\mathrm{x}$ & - \\
\hline 88 & Passeio Atlântico & - & - & - & - & $\mathrm{x}$ & $\mathrm{x}$ \\
\hline 89 & Quai des Gondoles & $\mathrm{x}$ & - & - & _- & $\mathrm{x}$ & - \\
\hline 90 & Elster and Pleiße Millraces & _- & - & _- & $x$ & $\mathrm{x}$ & _- \\
\hline 91 & Terreiro do Rato & - & - & - & $\mathrm{X}$ & $\mathrm{x}$ & - \\
\hline 92 & Waterfront promenade & $\mathrm{x}$ & - & - & $\mathrm{x}$ & $\mathrm{x}$ & - \\
\hline 93 & Elbe promenade & - & - & - & - & $x$ & $\mathrm{x}$ \\
\hline 94 & Dike of 'Boompjes' & $\mathrm{x}$ & $\mathrm{x}$ & $\mathrm{x}$ & - & $\mathrm{x}$ & $\mathrm{x}$ \\
\hline 95 & Zona de Banys del Fòrum & - & - & - & - & $x$ & $\mathrm{x}$ \\
\hline 96 & Molhe da Barra do Douro & - & _- & _- & _- & $x$ & $\mathrm{x}$ \\
\hline 97 & Jack Evans Harbour & - & - & - & - & $\mathrm{x}$ & $\mathrm{x}$ \\
\hline 98 & Schevenigen & - & - & - & - & $x$ & $\mathrm{x}$ \\
\hline 99 & Blackpool Seafront & - & - & - & - & $x$ & $\mathrm{x}$ \\
\hline 100 & Sea organ & - & - & - & - & $\mathrm{x}$ & $\mathrm{x}$ \\
\hline 101 & Main riverside & _- & - & _- & - & $\mathrm{x}$ & $\mathrm{x}$ \\
\hline 102 & Westhoven & - & - & - & - & $\mathrm{x}$ & $\mathrm{x}$ \\
\hline 103 & Wallkade promenade & - & - & _- & - & $\mathrm{x}$ & $\mathrm{x}$ \\
\hline 104 & Landungsbrücken building & - & - & - & - & $x$ & $\mathrm{x}$ \\
\hline 105 & Corktown Common & $\mathrm{x}$ & - & $x$ & - & $\mathrm{x}$ & $\mathrm{x}$ \\
\hline
\end{tabular}


As a result of the overall analysis of the classifications made for each example, it is possible to inaugurate some conclusions regarding the primary and secondary infrastructural strategies related to each type of measure. For instance, in light of three analyzed projects with different classifications (\#23,\#24 and \#25), cisterns have been classified with the infrastructural strategies of 'harvest', 'store', 'convey' and 'infiltrate'. It is however recognized that new or overlooked examples might potentially add new information. The same way that supplementary examples can add infrastructural qualifications for each type of measure, they can adjacently add new types of measures or categories that have not been yet addressed.

\subsection{The Doughnut Diagram: Assimilating Comprehension, Simplicity and Flexibility}

Recalling the methodological objectives regarding the framework's overall output, particular emphasis is given to its form and format. Considering the previously highlighted complexity of the proposed framework, in which measures can be associated with more than one infrastructural strategy, the initial communicating output in the form of a tree diagram proved to be very limitative. Indeed, the search for an alternative type of diagram was a continuously evolving design process.

In light of this reasoning, a doughnut diagram is thus proposed, combining a radial 'pie chart' with a potentially infinite range of 'classification rings'. While the radial 'pie chart' refers to the identified categories and types of measures, the classification rings refer to the chosen subject under analysis (type of flood, infrastructural strategy, physical extent of benefits, amongst others).

In the proposed framework, illustrated in Figure 8, the circular diagram is radially divided into 16 equal 'slices of pie'. Each 'slice' represents a category that is further divided into as many slices as its respective number of types of measures. Each ring refers to the chosen approach to classify each measure by its infrastructural strategies of 'harvest', 'store', 'infiltrate', 'convey', 'tolerate' and 'avoid'.

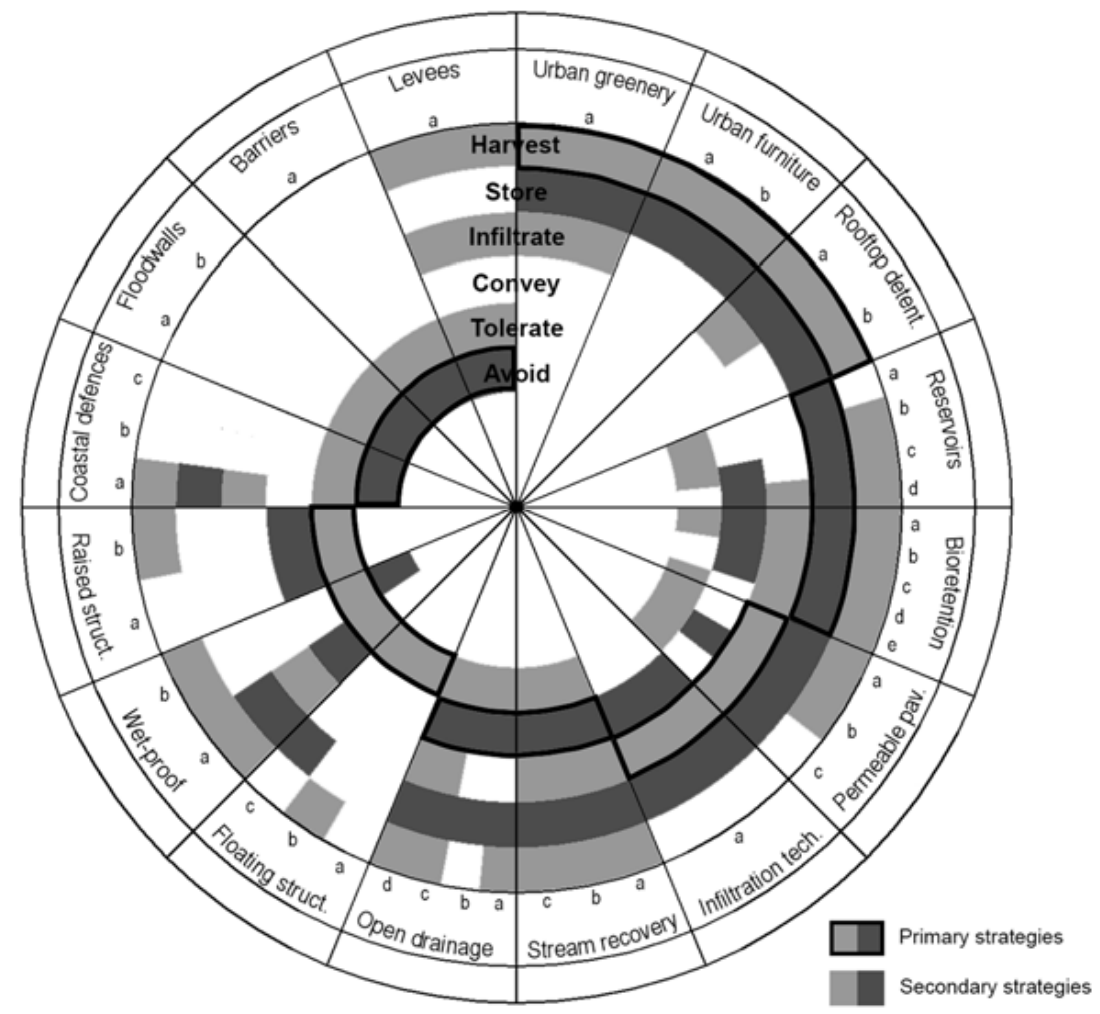

Figure 8. Flexible and comprehensive output of the proposed conceptual framework of flood adaptation measures applicable to the design of public spaces. 
The contents of the presented framework derive from the analysis of the classifications made for each example presented in Table 6. If one example is classified with a particular infrastructural strategy, then the type of measure associated with the analyzed example also encompasses that particular infrastructural strategy. Outlined segments of each ring highlight which categories and measures are considered as primary for each related strategy. For instance, regarding the category of 'Bioretention', the measure b of 'dry bioretention basin' encompasses the infrastructural strategies of 'harvest', 'store', 'infiltrate', 'convey' and 'tolerate', but not the infrastructural strategy of 'avoid'. The justification for this relates to the fact that, in light of the analyzed examples, no exemplar was classified by encompassing the infrastructural strategy of 'avoid'. Conversely, the infrastructural strategy of 'store' was highlighted as being the primary strategy among all analyzed examples.

Overall, through this proposed diagram, each category of measure, and its corresponding types, is associated with the main and secondary infrastructural strategies. This notwithstanding, and as already mentioned in this article, quality public spaces particularly favor interdisciplinary design and embrace multiple purposes. For this reason, when considering the measures associated with a particular infrastructural strategy, one should not only consider the ones that directly assist the respective strategy, but also the specific measures that indirectly support it. In other words, if one is to design a public space with flood adaptation aptitudes particularly directed towards the infrastructural strategy of 'store', then, besides the measures within the categories primarily aimed at this strategy (such as 'reservoirs' and 'bioretention'), the measures within categories of 'urban greenery', 'urban furniture', 'open drainage systems', 'stream recovery' or 'permeable paving' should be additionally considered (Figure 9a). In the case of Qunli Park (\#27), for example, the primary infrastructural purpose to 'store' stormwater and revitalize a dying wetland was complemented by the infrastructural strategies of 'harvest', 'infiltrate' and 'tolerate' in the design by Turenscape. More specifically, through the inclusion of specific native greenery, the processes of stormwater collection, filtration and infiltration are facilitated. In addition, by the inclusion of elevated promenades, the recreational and aesthetic experiences are reinforced, allowing visitors to fully acknowledge the surrounding natural environment.

Considering another practical example, if one is to design a public space with flood adaptation capacities particularly directed towards the infrastructural strategy to 'tolerate', then besides the measures within the categories primarily aimed at this strategy (such as 'floating structures', 'wet-proof' or 'raised structures'), the measures within categories of 'stream recovery', 'open drainage systems', 'coastal defenses', 'levees' or 'permeable paving' should also be considered (Figure 9b). In the case of Park Van Luna (\#87), for example, besides the primary purpose to 'Tolerate' flood waters, it additionally encompassed the infrastructural strategies of 'harvest', 'store' and 'convey'. Indeed, besides being implemented on a floodable polder landscape in The Netherlands, this park was further designed to store and conserve water during dry months. The design also entails a pumping system that, through conveyance, prevents water in the lakes from being stagnant. Moreover, albeit maintaining the 'soil balance', the design incorporates varied earthworks in the form of small levees.

The proposed framework has the additional potential to be disseminated through an 'open source' software medium where it is possible to add, remove or alter information within the supporting excel dataset through a simple Boolean logic of 'true' or 'false'. Examples, categories and types of measures can be added or removed, as can the classification made for each example be reassessed. As a result, different layouts within the same diagram can be generated. The same software medium could further include cross references to the literature review regarding the contents of the proposed framework, from the conceptual definitions, to the information supporting the classification process of each example. 


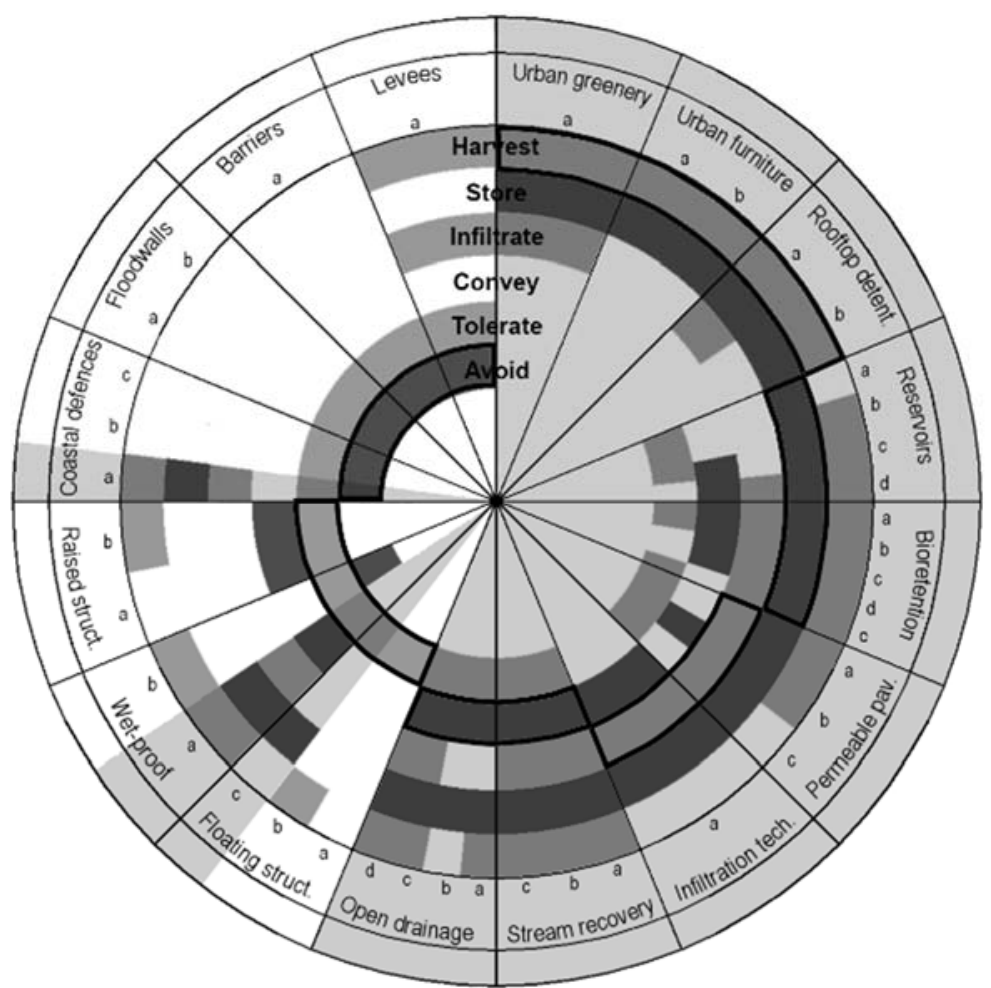

(a)

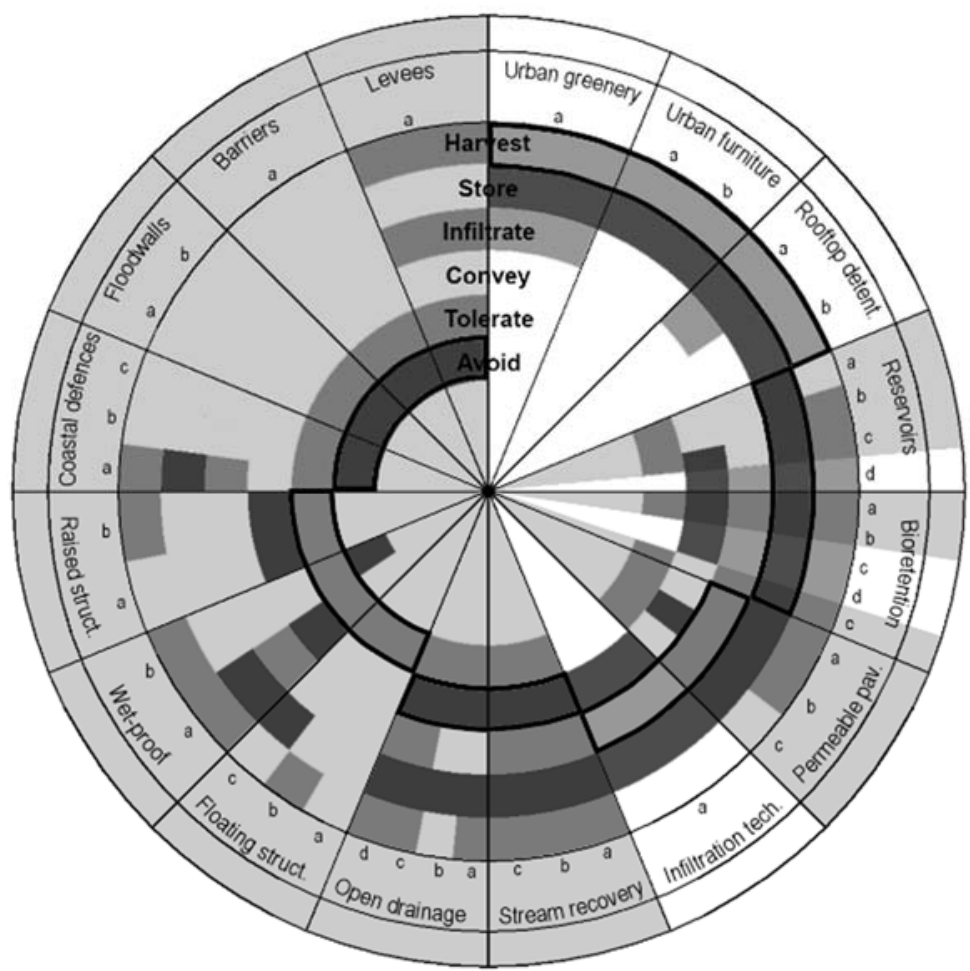

(b)

Figure 9. (a) Highlighted categories and types of measures, within the proposed framework, which encompass the infrastructural strategy to 'store' floodwaters; (b) highlighted categories and types of measures, within the proposed framework, which encompass the infrastructural strategy to 'tolerate' floodwaters. 


\section{Discussion}

The disclosed research is based on the premise that the application of local adaptation measures in the design of public spaces is determinant for the quality of future cities. Subsequently, this article specifically addresses the construction and design of a conceptual framework of flood adaptation measures that is concretely applicable to the design of public spaces. Bearing in mind the fundamental requirement to be sufficiently elucidated with regard to existing knowledge/practice when approaching any public space design project with flood adaptation capacities, the identification, characterization and organization of a wide range of existing types of measures is particularly relevant for anyone involved in this type of practice. The proposed framework is therefore targeted at supporting the initial stages of a respective design process. The possibility to easily grasp an overview of the existing range of options regarding the different types of adaptation measures facilitates and accelerates the initial phase of a particularly targeted design process. In addition, the resulting overlay of information, enabled by the proposed diagram, supports the envisioned purpose to design multifunctional public spaces. This, moreover, can be accomplished through an interdisciplinary implementation process, capable of tacking numerous questions while exploiting its beneficial opportunities.

A state of the art review on previously-developed frameworks supported the initial identification of the existing types and categories of measures. A systematization process, as envisioned, provided results of a general nature based on a comprehensive research of contextualized examples worldwide. Adjacent to this systematization process, examples were gathered with the purpose of supporting the ongoing classifications with illustrations of concrete situations specifically applied to public spaces. Ultimately, two tasks supported one another, as the collected range of examples also provided the identification of both new categories and associated measures. Each measure is therefore potentially applied within any geographical context. Thus, it is up to any individual involved in a respective public space design project with flood adaptation purposes to decide what is the best measure to be applied in a specific place.

Combining the literature review with the analysis of examples (portfolio screening), it was possible to identify thirty nine types of measures grouped within sixteen categories. These identified categories and types of measures can be differently organized in accordance with the diverse and particular purposes or contexts. The range of possible organizations is as wide as the various potential analysis of the identified types of measures and their corresponding examples. When opting to organize these categories and measures in a framework particularly directed at featuring their infrastructural relevance, it was additionally possible to classify each measure in light of the six infrastructural strategies of: 'harvest', 'store', 'infiltrate', 'convey', 'tolerate' and 'avoid'. Through the classification analysis of each collected example, all measures were related to one main infrastructural strategy and/or one or more than one secondary infrastructural strategy. The more examples are classified, the more accurate is the assessment made for each measure. Ultimately, the framework is expected to converge in a stable layout that displays all of the possible and impossible synergies amongst the different infrastructural strategies encompassed within each type of flood adaptation measure applied to the design of a public space.

In light of the disclosed results, one may note a strong correlation with the principles established by urban drainage management systems, such as SUDS, LID, BMPs, WSUD and more [20]. Yet, these differences essentially rely on the initial leading focus on 'adaptation to the risk of flooding'; more specifically, on the aim to include structural measures that not only support strategies of 'prevention', such as urban drainage management measures, but that also support 'protection' strategies, such as flood defense measures [19]. With regard to the presented framework, its distinctiveness can be found in the measures associated with the 'avoid' infrastructural strategy, such as 'breakwaters', 'sculptured walls', 'glass walls' or 'demountable barriers'. Other particularly targeted measures may be further identified in the remaining infrastructural strategies, namely 'inverted umbrellas', 'art installations', 'underground reservoirs', 'floating platforms', 'elevated promenades', among others. 
The resulting circular diagram synthetizes the framework's contents in a manageable format that is intended to be easily comprehended and used by anyone involved in the initial phases of a public space design project with flood adaptation purposes. The proposed framework therefore aids its users by presenting a wide range of options that are identified and characterized through a simple vocabulary and organized in a flexible and straightforward layout. Furthermore, through the use of the framework, options may be combined and creativity may be endorsed as each identified measure is associated with different potential and interrelating strategies.

Lastly, it is important to enforce that, both in method and structure, the design of the proposed framework always acknowledged the advantageous possibility to add new knowledge as it becomes available. It is therefore an "open work" [59], prepared to evolve and be restructured as new teachings, concepts or approaches arise. While the measures here proposed can provide a very useful starting point, most likely, and most fortunately, they will also change and derive as new challenges arrive.

\section{Conclusions}

The principal focus of the presented research refers to the importance of public space design in the climate change adaptation processes related to urban flooding. It is an issue that can be found at the core of an interdisciplinary design process and, as such, must not be strictly seen through an engineering perspective. The non-sectorial approach is, in fact, one of the greatest contributions of the proposed research. Specifically when facing the challenges presented by climate change and flood adaptation in particular, efforts should be targeted at enabling the convergence among disciplines [60]. Indeed, flood risk management has been essentially controlled by specific technical and specialized disciplines that have authoritatively decided upon the actions to take, either regarding coastal, riverine or pluvial flooding. Yet, nowadays, and as suggested by authors, such as White and Howe [61] and Lennon et al. [62], among others, this matter calls for improved knowledge and practice, where approaches are 'more comprehensive, not purely engineering' [63]. Approaches, in addition, embrace and integrate a broader range of stakeholders and disciplines, from the local community up to involved public companies, from landscape architects to climate change researchers, from urban planners to microclimate experts, among others. According to Coombes, integrated solutions will require the 'recognition of the need to collaborate across science, engineering, planning and sociological sectors in order to maximize the opportunities' [64].

In light of the abovementioned premises, all identified measures are equally considered and specifically classified according to a particular matter under analysis, be it implementation costs, environmental or social performance. The context of each case is what will dictate the selection of the most appropriate measures to be implemented. For example, through a strict and sometimes vital perspective to avoid floods, sustainable urban drainage may not replace the overall benefits gained by the implementation of a flood barrier. Hitherto, both sustainable urban drainage and flood barriers, if applied in a public space, here understood as a civic common space, a collective entity of shared concerns, may serve as social beacons for change [18].

Prompted by the urging need to adapt our cities in the face of potential climate change, the framework here proposed offers a different approach to tackle the well-known problem of urban flooding. Through a different perspective, one that highlights the importance of public space design in adaptation endeavors, this framework offers a specific group of measures that confront traditional flood risk management practices. Through the design of public spaces with flood adaptation capabilities, our urban territories may become better adapted for the projected unprecedented impacts of climatic change.

Acknowledgments: This research was supported by the Portuguese Foundation for Science and Technology funded by ‘Quadro de Referência Estratégico Nacional—Programa Operacional Potencial Humano (QREN-POPH), Tipologia 4.1-Formação Avançada, comparticipado pelo Fundo Social Europeu e por fundos nacionais do Ministério da Ciência, Tecnologia e Ensino Superior (MCTES)', under the individual doctoral grant (SFRH/BD/76010/2011); and by the Research Centre for Architecture, Urbanism and Design (CIAUD), University of Lisbon, Portugal. 
Author Contributions: The disclosed article introduces content that is developed in the doctoral thesis of Maria Matos Silva, with the title "Public space design and flooding: facing the challenges presented by climate change", integrated within the University of Barcelona in the subject-areas of Public Space and Urban Design. João Pedro Costa is the supervisor of the research and coordinates the research group on Urban Design and Climate Change Adaptation at CIAUD (Research Centre for Architecture, Urbanism and Design) at the Faculty of Architecture, University of Lisbon.

Conflicts of Interest: The authors declare no conflict of interest.

\section{Abbreviations and Acronyms}

ADAM-ADaptation and Mitigation Strategies: supporting European climate policy; ADAPT-Towards an integrated decision tool for adaptation measures; AMICA-Adaptation and Mitigation: an Integrated Climate Policy Approach; BMPs-Best management practices; $\mathrm{CABE}$-Commission for Architecture and the Built Environment; CAKE-Climate Adaptation Knowledge Exchange; CcSP/KvR—Climate 'changes' Spatial Planning/Klimaat voor Ruimte; ci:grasp-The Climate Impacts: Global and Regional Adaptation Support Platform; CIRCLE-2-Climate Impact Research \& Response Coordination for a Larger Europe; Climate-ADAPT-European Climate Adaptation Platform; ClimWatAdapt-Climate Adaptation: modelling water scenarios and sectorial impacts; EEA-European Environmental Agency; ESPACE-European Spatial Planning: Adapting to Climate Events; GRaBS—Green and Blue Space Adaptation for Urban Areas and Eco Towns; LID-low impact development; SUDS—Sustainable drainage systems; PPS-Project for Public Spaces; SWITCH-Managing Water for the City of the Future; TCPA-Town and Country Planning Association; UKCIP-United Kingdom Climate Impacts Programme; WeADAPT—Adaptation Planning, Research and Practice; WSUD—water sensitive urban design.

\section{References}

1. Intergovernmental Panel on Climate Change. Managing the Risks of Extreme Events and Disasters to Advance Climate Change Adaptation; Cambridge University Press: Cambridge, UK; New York, NY, USA, 2012.

2. Coumou, D.; Rahmstorf, S. A decade of weather extremes. Nat. Clim. Chang. 2012, 2, 491-496. [CrossRef]

3. Van de Ven, F.H.M.; Gersonius, B.; de Graaf, R.; Luijendijk, E.; Zevenbergen, C. Creating water robust urban environments in the netherlands: Linking spatial planning, design and asset management using a three-step approach. J. Flood Risk Manag. 2011, 4, 273-280.

4. Costa, J.P.; Sousa, J.F.D.; Silva, M.M.; Nouri, A. Climate change adaptation and urbanism: A developing agenda for lisbon within the twenty-first century. Urban Des. Int. 2014, 19, 77-91. [CrossRef]

5. Costa, J.P. Urbanismo e Adaptação às Alterações Climáticas, as Frentes de Água; Livros Horizonte: Lisboa, Portugal, 2013.

6. Ricart, N.; Remesar, A. Reflexiones sobre el espacio publico. Waterfront 2013, 25, 5-35.

7. Martin, L. The grid as generator. In Urban Design Reader; Carmona, M., Tiesdell, S., Eds.; Architectural Press: Oxford, UK, 2007; pp. 70-82.

8. Portas, N. Espaço público e a cidade emergente-os novos desafios. In Design de Espaço Público: Deslocação e Proximidade; Brandão, P., Remesar, A., Eds.; Centro Português de Design: Lisboa, Portugal, 2003; pp. 16-19.

9. Madanipour, A. Ambiguities of urban design. Town Plan. Rev. 1997, 68, 363-383. [CrossRef]

10. Brandão, P. Ética e Profissões, no Design Urbano. Convicção, Responsabilidade e Interdisciplinaridade. Traços da Identidade Profissional no Desenho da Cidade; Tese de Doctorado de Espacio Público e Regeneración Urbana, Arte y Sociedad, Universitat de Barcelona: Barcelona, Spain, 2004.

11. Arendt, H. The Human Condition, 2nd ed.; University of Chicago Press: Chicago, IL, USA, 1998; Original work published 1958.

12. Pelling, M. What determines vulnerability to floods: A case study in georgetown, Guyana. Environ. Urban. 1997, 9, 203-226. [CrossRef]

13. Ruddell, D.; Harlan, S.; Grossman-Clarke, S.; Chowell, G. Scales of perception: Public awareness of regional and neighborhood climates. Clim. Chang. 2012, 111, 581-607. [CrossRef] 
14. PPS (Project for Public Spaces). What Makes a Successful Place? Available online: http://www.pps.org/ reference/grplacefeat/ (accessed on 27 June 2013).

15. Jacobs, J. The Death and Life of Great American Cities; Random House: New York, NY, USA, 1992.

16. Commission for Architecture and the Built Environment. Public Space Lessons-Adapting Public Space to Climate Change; CABE Space: London, UK, 2008.

17. Matos Silva, M. Landscape: A Place of Cultivation. In Urban Adaptation through Flood Risk Management Infrastructure and Public Space Design; Silva, I.M.D., Marques, T.P., Andrade, G., Eds.; School of Sciences, University of Porto: Porto, Portugal, 2014; pp. 292-296.

18. Matos Silva, M.; Costa, J.P. Climate change and urbanism. A new role for public space design? In The Art of Urban Design in Urban Regeneration. Interdisciplinarity, Policies, Governance, Public Space; Remesar, A., Ed.; Publicacions I Edicions de la Universitat de Barcelona: Barcelona, Spain, 2016; pp. 62-86.

19. European Union. Flood risk management; flood prevention, protection and mitigation. In COM(2004)472 Final; Commission of the European Communities: Brussels, Belgium, 2004; p. 11.

20. Fletcher, T.D.; Shuster, W.; Hunt, W.F.; Ashley, R.; Butler, D.; Arthur, S.; Trowsdale, S.; Barraud, S.; Semadeni-Davies, A.; Bertrand-Krajewski, J.L.; et al. Suds, lid, bmps, wsud and more-The evolution and application of terminology surrounding urban drainage. Urban Water J. 2015, 12, 525-542. [CrossRef]

21. Matos Silva, M.; Nouri, A. Adaptation measures on riverfronts, an overview of the concepts. In Climate Change Adaptation in Urbanised Estuaries Contributes to the Lisbon Case; Costa, J.P., Sousa, J.F.D., Eds.; Várzea da Rainha Impressores: Óbidos, Portugal, 2014; pp. 131-150.

22. Adaptation Planning, Research and Practice. About Weadapt. Available online: http://weadapt.org/ knowledge-base/guidance/overview-of-weadapt (accessed on 4 June 2011).

23. United Kingdom Climate Impacts Programme. About Us. Available online: http://www.ukcip.org.uk/ about-ukcip/ (accessed on 28 June 2012).

24. Climate Adaptation Knowledge Exchange. About Cake. Available online: http://www.cakex.org/aboutcake (accessed on 5 June 2010).

25. European Climate Adaptation Platform. About Us. Available online: http://climate-adapt.eea.europa.eu/ about (accessed on 28 June 2012).

26. Climate 'changes' Spatial Planning. Climate 'Changes' Spatial Planning Programme. Available online: http:/ / www.climatechangesspatialplanning.nl/ (accessed on 2 June 2004).

27. Adaptation and Mitigation: An Integrated Climate Policy Approach. Matrix of Adaptation Measures. Available online: http:/ / www.amica-climate.net/online_tool.html (accessed on 4 June 2006).

28. ADaptation and Mitigation Strategies: Supporting European Climate Policy. Adam Digital Compendium-Home. Available online: http://adam-digital-compendium.pik-potsdam.de/ (accessed on 6 July 2009).

29. Green and Blue Space Adaptation for Urban Areas and Eco Towns. Green and Blue Space Adaptation for Urban Areas and Eco Towns. Available online: http:/ /www.ppgis.manchester.ac.uk/grabs/ (accessed on 10 July 2008).

30. ci:grasp. The Climate Impacts: Global and Regional Adaptation Support Platform. Available online: http:/ / pik-potsdam.de/cigrasp-2/ (accessed on 1 July 2008).

31. European Spatial Planning: Adapting to Climate Events. Available online: http://www.espace-project.org/ (accessed on 3 June 2007).

32. Hecq, W.; Giron, E.; Sacre, D.; Coninx, I.; Bachus, K.; Dewals, B.; Detrembleur, S.; Pirotton, M.; Kahloun, M.E.; Meire, P.; et al. Adapt-Towards an Integrated Decision Tool for Adaptation Measures. Case Study: Floods; Final Report (phase 1); Belgian Science Policy: Bruxelles, Belgium, 2008; p. 129.

33. Managing Water for the City of the Future. Available online: http://www.switchurbanwater.eu (accessed on 4 June 2006).

34. ClimWatAdapt. Why This Project? Available online: http:/ /www.climwatadapt.eu/ (accessed on 1 July 2010).

35. Foresight. Home. Available online: http://www.bis.gov.uk/foresight (accessed on 3 June 2012).

36. European Environment Agency. Urban Adaptation to Climate Change in Europe: Challenges and Opportunities for Cities Together with Supportive National and European Policies; Report No. 2/2012. European Environment Agency: Copenhagen, Denmark, 2012. 
37. European Environment Agency. Green Infrastructure and Territorial Cohesion: The Concept of Green Infrastructure and Its Integration into Policies Using Monitoring Systems; Report No. 18/2011; European Environment Agency, Publications Office of the European Union: Luxembourg, 2011.

38. Report on Good Practice Measures for Climate Change Adaptation in River Basin Management Plans. Available online: www.icm.eionet.europa.eu (accessed on 14 May 2011).

39. Town and Country Planning Association. Climate Change Adaptation by Design: A Guide for Sustainable Communities; TCPA: London, UK, 2001.

40. Climate Impact Research \& Response Coordination for a Larger Europe. Adaptation Inspiration Book-22 Implemented Cases of Local Climate Change Adaptation to Inspire European Citizens; Drukkerij Tienkamp: Groningen, The Netherlands, 2013.

41. Prominski, M.; Stokman, A.; Zeller, S.; Voermanek, D.S.A. River. Space. Design.: Planning Strategies, Methods and Projects for Urban Rivers; Birkhauser: Berlin, Switzerland, 2012.

42. Strijkers, D. Toolbox Adaptive Measures; Policopied Document by Doepel Strijkers Architects: Rotterdam, The Netherlands, 2011.

43. Hoyer, J.; Dickhaut, W.; Kronawitter, L.; Weber, B. Water Sensitive Urban Design. Principles and Inspiration for Sustainable Stormwater Management in the City of the Future. Manual; Deliverable 5.1.5; HafenCity Universität: Hamburg, Germany, 2011.

44. Ahern, J. From fail-safe to safe-to-fail: Sustainability and resilience in the new urban world. Landsc. Urban Plan. 2011, 100, 341-343. [CrossRef]

45. Nouri, A.S. A framework of thermal sensitive urban design benchmarks: Potentiating the longevity of auckland's public realm. Buildings 2015, 5, 252. [CrossRef]

46. Howe, C.A.; Butterworth, J.; Smout, I.K.; Duffy, A.M.; Vairavamoorthy, K. Sustainable Water Management in the City of the Future: Findings from the SWITCH Project 2006-2011; UNESCO-IHE: Katwijk, The Netherlands, 2011.

47. Coombes, P.J.; Barry, M.E. The effect of selection of time steps and average assumptions on the continuous simulation of rainwater cd harvesting strategies. Water Sci. Technol. 2007, 55, 125-133. [CrossRef] [PubMed]

48. Coombes, P.J.; Barry, M. A systems framework of big data for analysis of policy and strategy. In Proceedings of the WSUD \& IECA- $\mathrm{H}_{2}$ Olistic Integration: Concept Design, Construction and Operation, Sydney, Australia, 19-20 October 2015.

49. European Environment Agency (EEA). Towards Efficient Use of Water Resources in Europe; Report No. 1/2012. EEA: Copenhagen, Denmark, 2012.

50. Coombes, P.J.; Argue, J.R.; Kuczera, G. Figtree place: A case study in water sensitive urban development (wsud). Urban Water 1999, 1, 335-343. [CrossRef]

51. De Urbanisten. Water Square Benthemplein. Available online: http://www.urbanisten.nl (accessed on 31 May 2013).

52. Philip, R. Switch Training Kit-Integrated Urban Water Management in the City of the Future; ICLEI European Secretariat GmbH I Gino Van Begin: Freiburg, Germany, 2011.

53. Woods-Ballard, B.; Kellagher, R.; Martin, P.; Jefferies, C.; Bray, R.; Shaffer, P. The Suds Manual; CIRIA: London, UK, 2007.

54. Robinson, A.; Hopton, H.M. Case Study of Elmer Avenue Neighborhood Retrofit. Landscape Performance Seriesp; Landscape Architecture Foundation. Available online: http:/ /landscapeperformance.org/ (accessed on 12 January 2016).

55. Kwon, K.-W. Cheong Gye Cheon Restoration Project, a Revolution in Seoul; Seoul Metropolitan Government: Seoul, Korea, 2007.

56. Turenscape. Available online: http://www.turenscape.com/ (accessed on 1 June 2016).

57. Valera, S. La percepció del risc. In Com "Sentim" el Risc, Observatori del Risc, Informe 2001th ed.; Mir, N., Ed.; Beta Editorial: Barcelona, Spain, 2001; pp. 235-261.

58. Flood Control International. Glass Barriers-Data Sheet. Available online: http://www. floodcontrolinternational.com (accessed on 14 May 2015).

59. Eco, U. The Open Work; Harvard University Press: Cambridge, MA, USA, 1989.

60. Meyer, H. Urban design in a dynamic delta. In Proceedings of the Institution of Civil Engineers; Urban Design and Planning: London, UK, 2010; pp. 1-13.

61. White, I.; Howe, J. The mismanagement of surface water. Appl. Geogr. 2004, 24, 261-280. [CrossRef] 
62. Lennon, M.; Scott, M.; O'Neill, E. Urban design and adapting to flood risk: The role of green infrastructure. J. Urban Des. 2014, 19, 745-758. [CrossRef]

63. Hartmann, T.; Driessen, P. The flood risk management plan: Towards spatial water governance. J. Flood Risk Manag. 2013, 1-10. [CrossRef]

64. Coombes, P.J. Transitioning Drainage into Urban Water Cycle Management; 9th International Water Sensitive Urban Design (WSUD); Engineers Australia: Barton, Australia, 2015; pp. 79-88.

(C) 2016 by the authors; licensee MDPI, Basel, Switzerland. This article is an open access article distributed under the terms and conditions of the Creative Commons Attribution (CC-BY) license (http://creativecommons.org/licenses/by/4.0/). 